\title{
Article \\ Operationalizing the Circular City Model for Naples' City-Port: A Hybrid Development Strategy
}

\author{
Maria Cerreta ${ }^{1, *}$, Eleonora Giovene di Girasole ${ }^{2} \mathbb{1}$, Giuliano Poli ${ }^{1}$ and Stefania Regalbuto ${ }^{1}$ \\ 1 Department of Architecture, University of Naples Federico II, 80134 Naples, Italy; \\ giuliano.poli@unina.it (G.P.); stefania.regalbuto@unina.it (S.R.) \\ 2 Institute for Research on Innovation and Services for Development (IRISS), National Research Council of \\ Italy (CNR), via Cardinale Guglielmo Sanfelice, 80134 Naples, Italy; e.giovenedigirasole@iriss.cnr.it \\ * Correspondence: maria.cerreta@unina.it
}

Received: 7 January 2020; Accepted: 25 March 2020; Published: 7 April 2020

\begin{abstract}
The city-port context involves a decisive reality for the economic development of territories and nations, capable of significantly influencing the conditions of well-being and quality of life, and of making the Circular City Model (CCM) operational, preserving and enhancing seas and marine resources in a sustainable way. This can be achieved through the construction of appropriate production and consumption models, with attention to relations with the urban and territorial system. This paper presents an adaptive decision-making process for Naples (Italy) commercial port's development strategies, aimed at re-establishing a sustainable city-port relationship and making Circular Economy (CE) principles operative. The approach has aimed at implementing a CCM by operationalizing European recommendations provided within both the Sustainable Development Goals (SDGs) framework-specifically focusing on goals 9, 11 and 12-and the Maritime Spatial Planning European Directive 2014/89, to face conflicts about the overlapping areas of the city-port through multidimensional evaluations' principles and tools. In this perspective, a four-step methodological framework has been structured applying a place-based approach with mixed evaluation methods, eliciting soft and hard knowledge domains, which have been expressed and assessed by a core set of Sustainability Indicators (SI), linked to SDGs. The contribution outcomes have been centred on the assessment of three design alternatives for the East Naples port and the development of a hybrid regeneration scenario consistent with CE and sustainability principles. The structured decision-making process has allowed us to test how an adaptive approach can expand the knowledge base underpinning policy design and decisions to achieve better outcomes and cultivate a broad civic and technical engagement, that can enhance the legitimacy and transparency of policies.
\end{abstract}

Keywords: circular economy principles; city-port development strategy; sustainable indicators; role-playing game; PROMETHEE method; stakeholders analysis; multidimensional evaluation; adaptive decision-making process

\section{Introduction}

The concept of urban development according to the Urban Agenda [1,2] recognizes that cities play an essential role in the development of Circular Economy (CE) processes, allowing potential measures to influence circular consumption, urban resource management, circular business enablers and drivers, and governance, in order to implement the Circular City Model (CCM) [3-5]. Within a cross-scale perspective, the idea of CCM provides the theoretical framework within which to identify, elaborate and assess urban and territorial sustainable development and regenerative strategies. 
In order to operationalize sustainability targets, CE principles can help structure an evaluative methodological approach to manage the transition [6,7]. Regarded as a "place-based" and "use-inspired" transition, the CCM leverages knowledge systems and developmental change methodologies to support the sustainability paradigm shift, where the city and its dynamics have a central role, and the city-port identifies a specific enabling context [8-11]. In the past, over the centuries, harbour spaces have strongly influenced urban identity and urban morphology, shaping spatial features and functions, both at a local and regional level. They were considered the core of the city and its economic and social driving force [12-16], activating complementary and symbiotic relationships between the sea, the coast, the city and the territory [8]. This symbiosis has been interrupted over time, generating an ever greater separation of the port from the city, both with respect to the functions and the system of relations, due to a growing need for autonomy and expansion spaces [17,18]. Nowadays, the harbour requests autonomy and spaces, while the city claims integration and dialogue. The European Committee of the Regions underlines that cities and port areas are an essential component of the economic system of the European Union, which strongly influences, under conditions of increasing globalization, the possibility of relaunching growth, improving efficiency and stimulating innovation and long-term competitiveness [19].

In this perspective, the ports have been recognized as a strategic hub, an engine for growth, both for the transportation system and economic competitiveness, due to their high potential in terms of job opportunities and investments [20]. Nevertheless, developing these activities, and consequently extending the spaces of logistics, is expected to impact the cities in economic, social and environmental terms, negatively influencing the well-being and the quality of life [12,21-25].

In order to frame and implement the CCM processes for the sustainable development of port-cities, it is possible to refer, on the one hand, to the Sustainable Development Goals (SDGs) $[26,27]$ and, on the other hand, to the Maritime Spatial Planning of the European Directive 2014/89) [28], elaborating adaptive multidimensional decision-making processes able to integrate evaluative approaches and tools, useful to account for complex interactions and face conflicts in the overlapping areas of the city-port [29]. According to an ecosystem-based approach, to promote a sustainable future development, the United Nations [26-28] have identified 17 Sustainable Development Goals (SDGs), which require complementary actions by governments, civil society, science, and businesses. In particular, it is interesting to work on processes of transformation and sustainable development exploring strong interdependencies between the 17 SDGs, their integrated and complementary relationships and potential synergies and multiple co-benefits [30-32]. The approach of SDGs is particularly significant for the planning of coastal areas and port cities, which require complex urban and maritime transformation processes, considering the long-term horizon in which the guidelines for urban planning unfold and the impacts that these actions have on the territories from an environmental, economic and socio-cultural point of view. A further reference to examine the issues of sustainability, related to the development of port-cities, is the Maritime Spatial Planning [28]. The European Directive, in order to promote the sustainable growth of maritime economies, the sustainable development of marine areas and the sustainable use of marine resources, acknowledging the programmatic objectives of the previous directives, recognizes the planning of maritime space as a decisive tool, able to consider and integrate economic, social and environmental aspects. In line with this approach, in Italy, in 2017, the "Guidelines containing the criteria for the management of the maritime space" $[28,33]$ were elaborated. The planning of the maritime space is configured as a process, which, starting from the identification and clarification of the macroconflicts and the synergies that characterize it, intends to respond to real problems, through the definition of an adequate management plan. The process is divided into different phases, which include the gathering of information, the adoption of decisions, the implementation, the revision and/or updating and the control of the execution, taking into due consideration the land-sea interactions and the best knowledge available, and involving the various stakeholders. In this context, merging methodological research approaches around the complexity of urban port systems and integrated assessment approaches, understood as structured and 
adaptive processes which guide and support the elaboration of decisions and the choice of preferable scenarios, implies dealing with situations of uncertainty and value conflicts that sometimes cannot be overcome only through the use of traditional tools [34-36]. Therefore, facing the challenge of the sustainability of circular port-cities implies structuring decision-making processes consistent with the Agenda 2030 objectives and the Maritime Spatial Planning directive, activating contexts open to the constant and synergistic interaction between knowledge and skills, in which integrated evaluation approaches [22] can play a decisive role.

Therefore, the paper presents an adaptive decision-making process for Naples (Italy) commercial port's development strategies, aimed at re-establishing a sustainable city-port relationship and making CE principles operative.

The methodological approach was developed within the Italian research Project of Relevant National Interest (PRIN, 2015) "Metropolitan cities: territorial economic strategies, financial constraints, and circular regeneration", coordinated by the Polytechnic of Milan, where the CCM has been explored with particular attention to the city-port and the metropolitan city of Naples.

The decision-making process was elaborated and tested within the urban laboratory activity of the Master in "Sustainable Design and Planning of Port Areas", at the Department of Architecture (DiARC) of the University of Naples Federico II, in order to support the Metropolitan City of Naples and the Port System Authority of the Central Tyrrhenian Sea (AdSP) in the identification of alternative strategies for the regeneration of the East Naples port area.

The approach has aimed at implementing a CCM by operationalizing the European recommendations provided within both the Sustainable Development Goals (SDGs) framework-specifically focusing on the goals 9, 11 and 12-and the Maritime Spatial Planning European Directive 2014/89, to face conflicts about the overlapping areas of the city-port, through multidimensional evaluations' principles and tools.

The paper, in Section 2, introduces materials and methods of the adaptive, place-based, multidimensional and multimethodological decision-making process, elaborated for the city-port system of East Naples (Italy) in order to identify a hybrid development strategy able to implement the CCM; in Section 3, a four-step methodological framework of the proposed approach has been applied to the case study; in Section 4, the results have been described; and in Section 5, the discussion of the potentials and critical aspects, as well as a conclusion suggesting future research steps, are presented.

\section{Materials and Methods}

The primary purpose of this study is the elaboration of an evaluative framework for the definition and experimentation of a multidisciplinary and integrated methodology, which can help structure an adaptive decision-making process useful to implement the CCM and oriented to supporting the elaboration of a spatial transformation and development strategy with regard to port-cities. According to the above perspective, the goal is to design a sustainable and circular development of the city-port system of Naples (Italy), considering East Naples' harbour and the San Giovanni a Teduccio neighbourhood, and recognizing the crucial role of an integrated and multimethodological approach $[22,34]$ able to support the elaboration and selection of future scenarios, by considering the following drivers:

- the observation and interpretation of the harbour's complex relation with the surrounding urban context;

- the provisioning of different scenarios based on the synergy between the harbour's logistics and various urban functions;

- the evaluation of the features of identity-related places and the needs of local communities.

Within this context, the methodological workflow has been carried out through four operational steps (Figure 1). The proposed methodological framework applies a place-based and adaptive approach with mixed evaluation methods, eliciting soft and hard knowledge domains, which have been expressed 
and evaluated through a core set of Sustainability Indicators (SI) linked to the Sustainable Development Goals (SDGs) $[27,30]$. The operational steps will be described in detail in the following subsections.

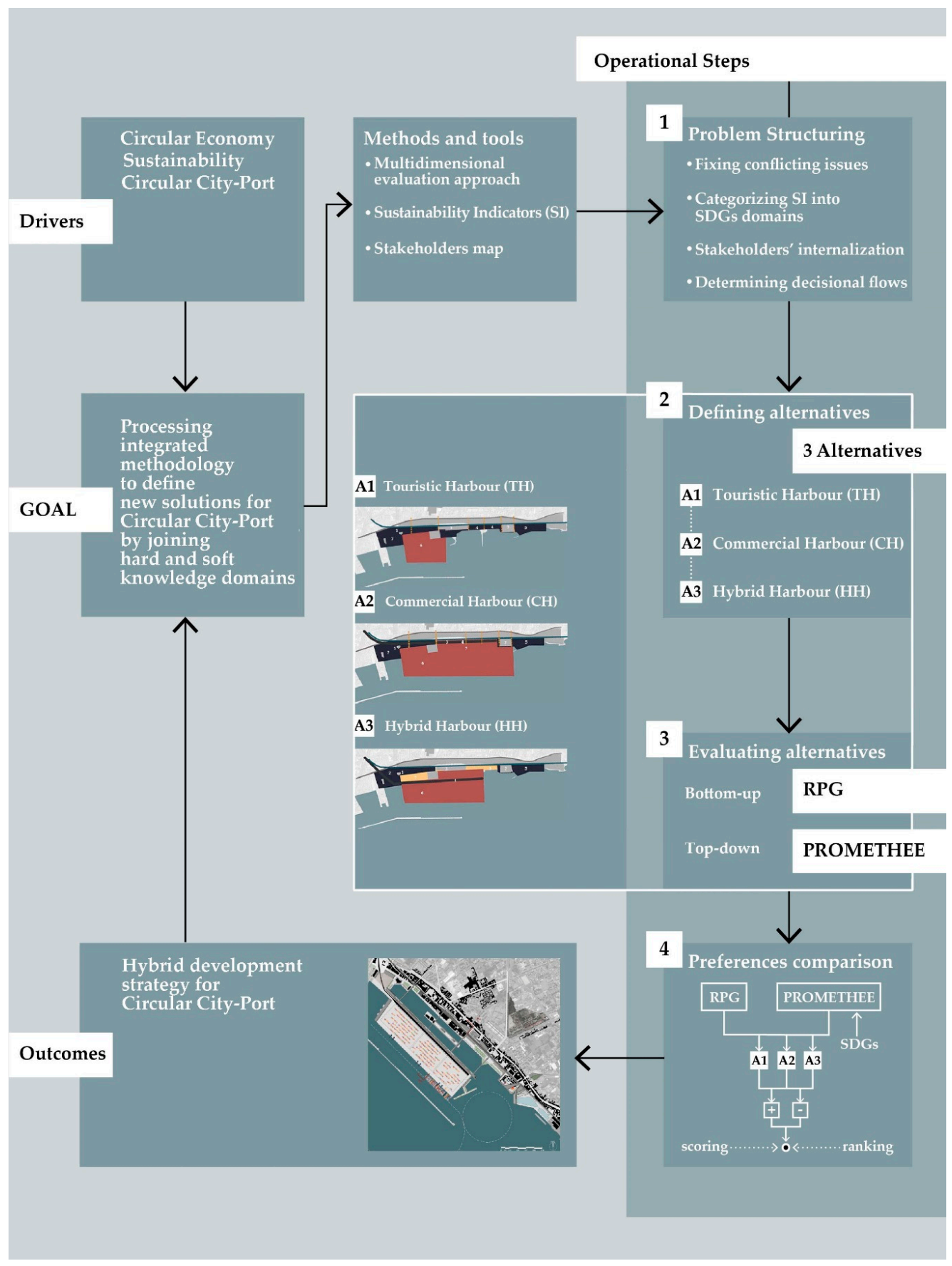

Figure 1. Methodological framework.

\subsection{Problem Structuring}

The multifunctionality and multidimensionality of decision-making processes have to be strongly considered when dealing with complex flows related to the logistics, the city-port interaction zones, the multimodal transport systems, the definition of the harbour layout and the provisioning of functions and services that fit with the urban and public spaces.

The overlapping of these issues necessarily requires the coexistence of diversified skills and backgrounds. Structuring the decision-making problem considering the main issues arising from 
public debate is the crucial step for elaborating, evaluating and defining multidimensional solutions. The knowledge acquisition about complex flows and correlated phenomena is expected to be a structured process, whereby data coming from different sources must be organized in well-defined categories and processed into meaningful indicators. Nevertheless, the knowledge deriving from institutional sources must necessarily be combined with direct investigation of the so-called "soft dimensions". In this way, the local communities and social networks can play an essential role in communicating criticalities and potentials, as well as needs and requirements. Moreover, the identification of significant stakeholders is one of the crucial phases, since it is useful for understanding the institutional context and the different interests that arise within complex decision-making arenas. Indeed, directing the choice towards a vision of balanced development and CE implies the effort to evaluate compromise solutions that can reduce the trade-offs and, concurrently, to afford different instances effectively and coherently.

\subsection{Defining Alternatives}

Generating design alternatives allows for the forecasting of different development scenarios, according to economic, social and environmental trends, to the main interests of the stakeholders involved and to the spatial configuration of the city-port. Three main alternatives that correspond, respectively, to touristic, commercial and hybrid visions of development for Naples' harbour and the San Giovanni a Teduccio neighbourhood have been defined and drawn. The best-fit design alternative should lead to a mediation among urban neighbourhoods and port authority spaces, and its choice must be determined to take into account conflicting needs and interests about functions, spaces and their relation systems.

\subsection{Evaluating Alternatives}

The operational skills of the multidimensional assessment tools have been used to solve complex problems. Two streams of evaluation, which lead, respectively, to hard and soft knowledge elicitation, have been requested by the decision-making problem structure, in order to answer two main typologies of issues.

The first stream tried to answer the following typologies of questions: Which opportunities and threats derive from each of the three proposed alternatives? What about the needs and concerns of people living within the influence area of the harbours?

The Role-Playing Method (RPM) $[37,38]$ has been selected as the most useful tool to gather the preferences of citizens dynamically and fast. The outcome of RPM is a scoring process that shows the participants' preferences with respect to the proposed alternatives.

The second stream concerns instead the following questions: How to evaluate the performances of design alternatives with respect to sustainability and CE instances? Which SDGs must be considered? Furthermore, in this perspective, what are the preferences of the most influential stakeholders?

The Preference Ranking Organization Method for Enrichment Evaluation (PROMETHEE)'s multicriteria method [39-41] has been chosen, since it allows us to analyse different scenarios that show the visions of the main stakeholders engaged and, consequently, performs a total ranking of alternatives based on the aggregation of all the stakeholders' judgements.

\subsection{Preference Comparison}

Comparing the results of the evaluation and analysing the scores of the different alternatives encourages the choice of balanced solutions that try to reduce conflicts. Indeed, matching the PROMETHEE ranking with the RPM scoring means investigating the opportunities and threats which have been expressed during the RPM rounds and the ability to pursue each alternative about SI through PROMETHEE bar charts. The review of the results helps decision-makers and experts design new complex visions of development for the city-port system. 


\subsection{Outcome}

The preferable-fit alternative, taking into account complex issues, needs and conflicting points of view, has been shaped like one of the possible spatial configurations for circular city-port development. A master plan has been drawn laying out a flexible vision for the future, which is attentive to the continuous change in the economic, environmental and social conditions of the intervention context.

\section{A Multidimensional Decision-Making Process for the Regeneration of the East Naples City-Port System}

Aiming at testing and developing the above proposed adaptive multimethodological decision-making process, the port of East Naples (Italy) trading area has been selected as a case study. Localized on the east side of the Gulf of Naples, the focus area extends within the VI Municipality of Naples Metropolitan City, in the San Giovanni a Teduccio neighbourhood (Figure 2).

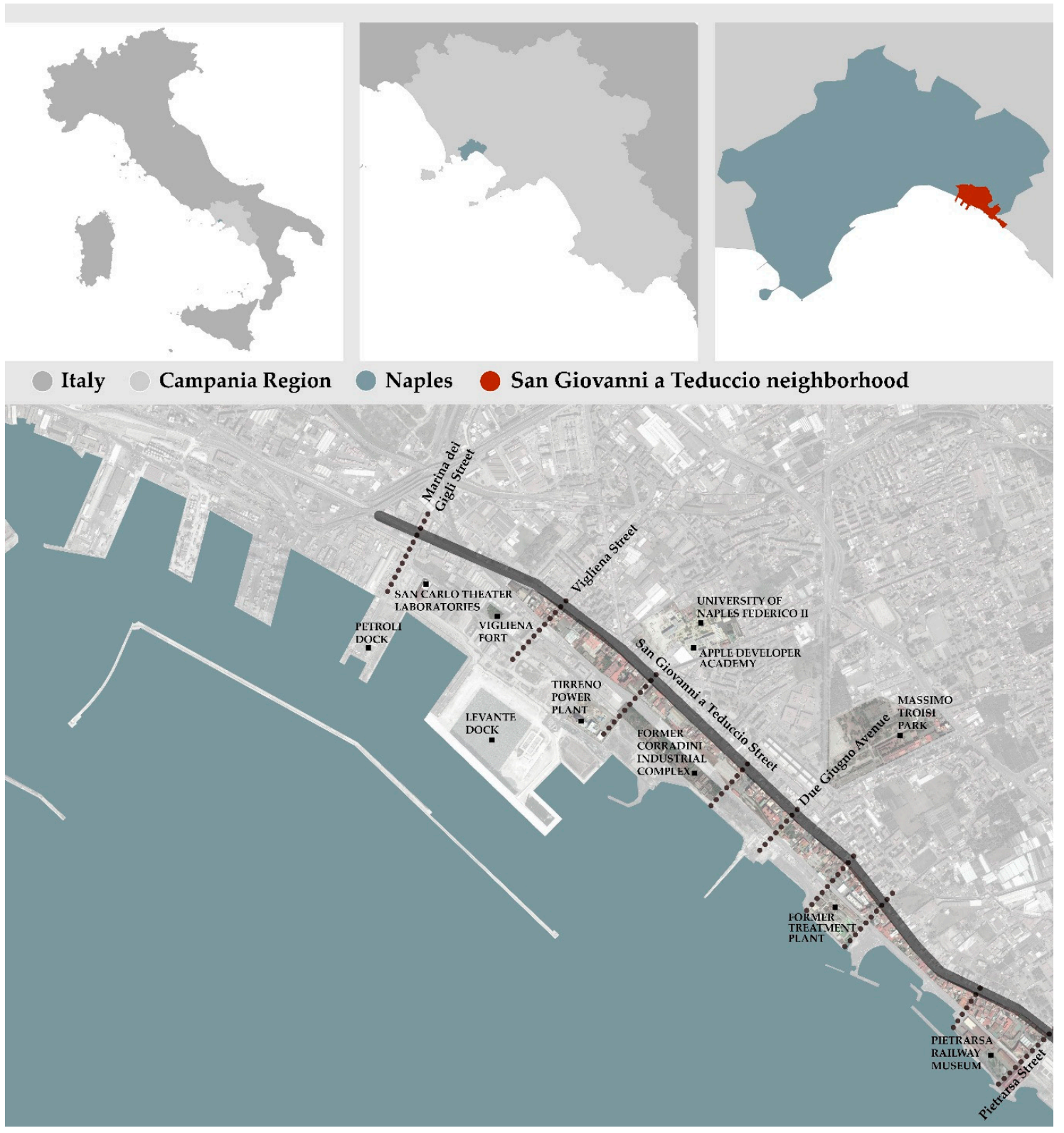

Figure 2. The focus area: San Giovanni a Teduccio port area. 
Although it was formerly agricultural, the area experienced the urbanization process due to the construction of the Naples-Portici passenger railway, dating back to 1839, and reached its maximal economic and property development during the industrial age. As a consequence of the changing pattern of land use which took place in the post-industrial era, the coastal area of San Giovanni a Teduccio is currently marked by the widespread presence of residential properties (the population density is approximately $6841.9 / \mathrm{km}$ ), abandoned industrial buildings and brownfields, strengthening the previous caesura between port and city. Moreover, the strong decrease in demand for industrial activities led to a significant employment crisis. Suffice it to say that out of 11,159 inhabitants the unemployment rate amounts to $36.5 \%$, whereas the rate of youth unemployment is $69.4 \%$.

The boundaries of the focus area, extending between Petroli Dock and the Pietrarsa Railway Museum, are San Giovanni a Teduccio Street, to the north, and the coastline, to the south. Furthermore, the railway, as well as the road network crossing it and the largely disused pre-existing buildings that serve as urban landmarks, divide the area into five parts.

The inaccessibility, together with the progressive abandonment of the industrial activities once located in the area, has caused brownfields and drosscapes [42], also known as "non-port places" or "non-place ports" [43], to arise.

In particular, in the sector between Petroli Dock and Vigliena Street, within a largely disused industrial and residential area, there is the former Cirio factory, already redeveloped and repurposed as the San Carlo Theatre laboratories, in addition to the Vigliena Fort, currently abandoned. Continuing eastwards, Levante Dock is now occupied by the Tirreno power plant, beyond the former Corradini factory, a disused industrial complex close to the Naples-Portici railway, extending up to Due Giugno Street. Still further east, along the coastline, stands the former treatment plant, now almost wholly abandoned. Finally, in the area of Pietrarsa Street, the former steel industry is now occupied by a Railway Museum.

Extending over the coastal strip between the residential district and the port authority zone, the focus area lies within the city-port settlement as an enclave whose administrative boundaries are regulated by two policy systems: the Metropolitan City of Naples and the Port System Authority of the Central Tyrrhenian Sea (AdSP).

In line with the objectives of Italian legislative decree no. 169/2016, within the cross-scale and place-based theoretical framework provided by the concept of regenerative development, a strategy that is able to overcome the fragmentation of local interests, thus enhancing the city-port system's attractiveness and competitiveness for both internal and external markets, is being pursued. Indeed, according to the recent literature, port areas, as the result of their geographical location, have often been the flywheel for economic and social development at the regional scope [23,44].

In this context, the aforementioned multimethodological decision-making process, aiming to trigger the development of the city-port system—a regenerative strategy for the San Giovanni a Teduccio coastal area that takes into account its multiple domains and stakeholders-has been proposed.

First of all, large amounts of data with different features have been collected and then structured into the SIs database. A more in-depth approach has been pursued, in order to draw up a knowledge-based system and support decision makers (DM) in their choices regarding urban transformation, decision problem structuring and the subsequent definition of suitable design alternatives, combining an appropriate set of indicators with institutional analysis results.

Moreover, to aid DMs in choosing the best-fit alternative among a feasible set, structuring soft and hard data and employing Multi-Criteria Decision Making (MCDM) methods as part of the Decision Support System (DSS)'s methodological approach [45,46], the evaluation of three alternative development scenarios has been carried out.

\subsection{Sustainability Indicators and Sustainable Development Goals: Relationships and Interactions}

According to the Agenda 21 (Chapter 40) and the United Nations' Conference on Sustainable Development (UNCSD, or “Rio+20"), convened in 20-22 June 2012, in Rio de Janeiro, Brazil, quantifying 
information and categorizing data into structured indicators play a relevant role when simple or composite indicators have been conceived as proxies to measure the sustainability thresholds and, concurrently, circular economy values $[47,48]$. In this paper, the indicators have been used as tools for operationalizing, monitoring and assessing the SDGs' targets at the local scope. Since the information gap on the study area was relevant and current data needed, it was not feasible to compute the SDGs at the local scale. Instead, a new selection of indicators has been done considering SDGs 9, 11 and 12 [26] (Figure 3).

Specifically, Goal 9, "Industry, innovation, and infrastructure", considers that investments in infrastructure and innovation are crucial drivers of economic growth and development, with specific attention to the growth of new industries and information and communication technologies, capable of providing new jobs and promoting energy efficiency.

At the same time, according to Goal 11, "Sustainable cities and communities", significantly transforming the ways of building and managing urban spaces to make cities sustainable means creating career and business opportunities, safe and affordable housing, and building resilient societies and economies. This involves an investment in public transport, creating green public spaces and improving urban planning and management in participatory and inclusive ways.

Furthermore, Goal 12, "Responsible consumption and production", underlines that achieving economic growth and sustainable development requires the urgent reduction of our ecological footprint by changing the ways in which we produce and consume goods and resources. According to this Goal, the efficient management of natural resources and the recycling and reducing of waste are equally important to move towards more sustainable patterns of consumption by 2030, and for creating more efficient production and supply chains.

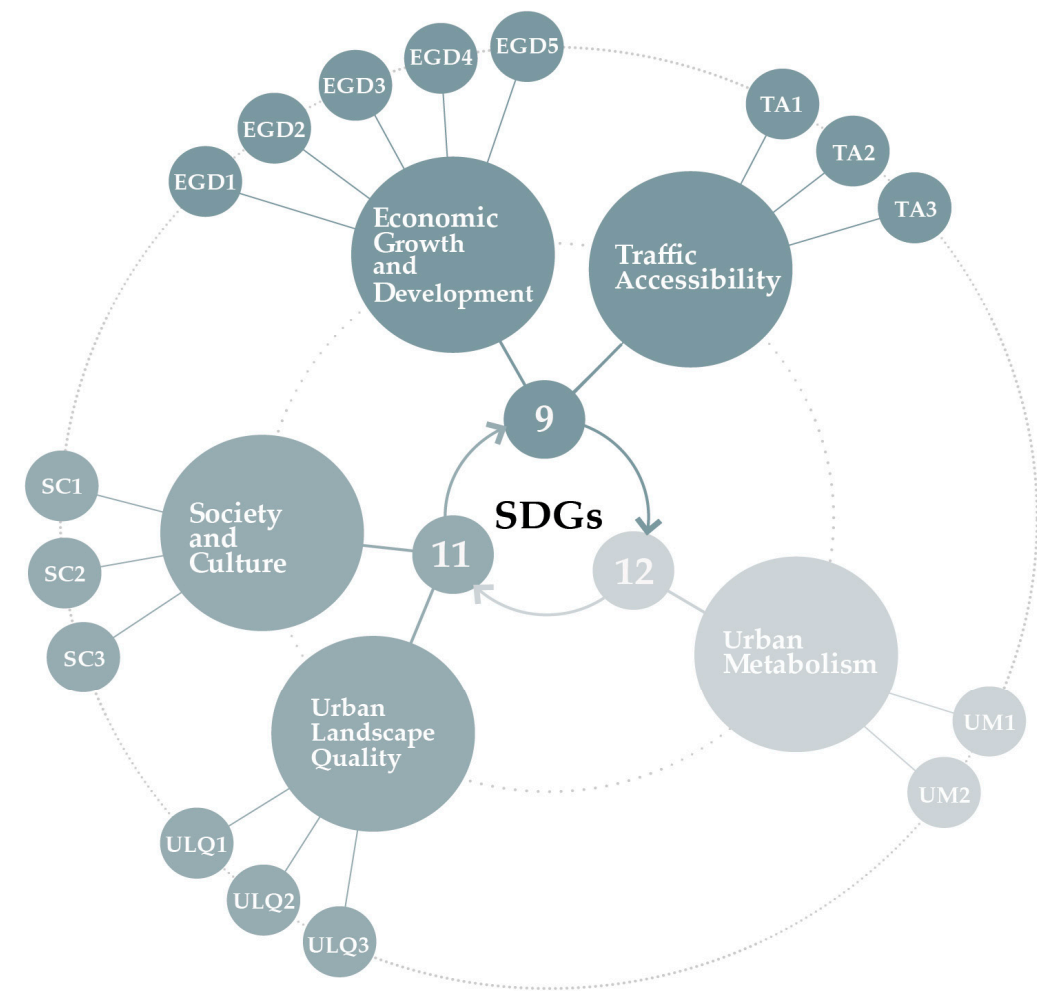

Figure 3. The relationship between the Sustainable Development Goals (SDGs) and Sustainability Indicators (SIs) domains.

Taking into account the selected Goals, the new indicators have been formulated according to site-specific issues which have been categorized into five relevant domains for city-port regeneration. The domains mentioned above-which relate to Economic Growth and Development, Traffic 
Accessibility, Urban Metabolism, Society and Culture, Urban Landscape Quality—have been made explicit by subsets of Sustainability Indicators (SIs) [29], amounting to a total of sixteen indicators. Table 1 shows the indicators list, highlighting five domains: code, indicator source (IS), data source (DS), unit of measure (UM) and indicators' value (Table 1).

Table 1. Sustainability Indicators (SIs).

\begin{tabular}{|c|c|c|c|c|c|}
\hline Domain & Code & Indicator & IS/DS ${ }^{1}$ & $\mathrm{UM}^{2}$ & Value \\
\hline \multirow{5}{*}{$\begin{array}{l}\text { Economic } \\
\text { Growth and } \\
\text { Development } \\
\text { (EGD) }\end{array}$} & EGD1 & Costs & $\begin{array}{l}\text { Authors } \\
\text { elaboration }\end{array}$ & $\operatorname{mln} €$ & 0 \\
\hline & EGD2 & Job potential & $\begin{array}{l}\text { ITACA/ } \\
\text { ISTAT }\end{array}$ & $\%$ & 14.6 \\
\hline & EGD3 & Unemployment rate & $\begin{array}{l}\text { LEED/ } \\
\text { ISTAT }\end{array}$ & $\%$ & 13.2 \\
\hline & EGD4 & $\begin{array}{l}\text { Incidence of high-medium } \\
\text { specialized jobs }\end{array}$ & ISTAT & $\%$ & 19.9 \\
\hline & EGD5 & $\begin{array}{l}\text { Incidence of low } \\
\text { specialized jobs }\end{array}$ & ISTAT & $\%$ & 24.9 \\
\hline \multirow{3}{*}{$\begin{array}{c}\text { Traffic } \\
\text { Accessibility } \\
\text { (TA) }\end{array}$} & TA1 & Cargo handling (import) & ISPRA & TEU $^{3}$ & 536,917 \\
\hline & TA2 & Cargo handling (export) & & TEU & 499,631 \\
\hline & TA3 & Number of docks & & TEU & 828 \\
\hline \multirow{2}{*}{$\begin{array}{l}\text { Urban } \\
\text { Metabolism } \\
\text { (UM) }\end{array}$} & UM1 & Air quality index (AQI) & $\begin{array}{l}\text { LEED/ } \\
\text { ISPRA }\end{array}$ & $\mathrm{mg} / \mathrm{Nm} 3$ & 40.9 \\
\hline & UM2 & $\begin{array}{c}\text { Organic Municipal Solid } \\
\text { Waste (OW-MSW) recycled } \\
\text { in the district }\end{array}$ & $\begin{array}{l}\text { LEED/ } \\
\text { ISPRA }\end{array}$ & ton/year & 0 \\
\hline \multirow{3}{*}{$\begin{array}{c}\text { Society } \\
\text { and Culture } \\
\text { (SC) }\end{array}$} & SC1 & $\begin{array}{c}\text { Number of } \\
\text { social-cultural associations }\end{array}$ & EC/Survey & num. & 8 \\
\hline & SC2 & $\begin{array}{c}\text { Number of } \\
\text { cultural services }\end{array}$ & EC/Survey & num. & 10 \\
\hline & SC3 & $\begin{array}{c}\text { Number of high schools } \\
\text { involved in } \\
\text { cultural initiatives }\end{array}$ & EC/Survey & num. & 8 \\
\hline \multirow{3}{*}{$\begin{array}{c}\text { Urban } \\
\text { Landscape } \\
\text { Quality (ULQ) }\end{array}$} & ULQ1 & $\begin{array}{l}\text { Walkability (length of } \\
\text { pedestrian path) }\end{array}$ & ITACA & $\mathrm{Km}$ & 2.23 \\
\hline & ULQ2 & Drosscapes & $\mathrm{EC} / \mathrm{MEF}$ & $\mathrm{mq}$ & 62.03 \\
\hline & ULQ3 & Green public spaces & ITACA/ OSM & he & 3.66 \\
\hline
\end{tabular}

${ }^{1}$ Indicator Source (IS)/Data Source (DS); ${ }^{2}$ Unit of Measure (UM); ${ }^{3}$ Twenty-foot Equivalent Unit (TEU).

The formulated SIs have been used as a monitoring set and tested on a focus area which includes the San Giovanni a Teduccio neighbourhood and Naples' port trading zones. According to the conceptual approach, the core set of indicators, which are independent of political agendas, has been based on models of sustainable development and CE processes for city-port regeneration [49-51]. Nevertheless, the selection of indicators has also been derived from the main issues emerged during the public debate with local stakeholders about the future development of Naples' harbour. On the one hand, the indicators have been used to quantify and easily communicate complex information about the area of investigation; on the other hand, they have been set as evaluation parameters to produce scenarios with the stakeholders' points of view. According to Rodriguez-Anton et al. [52], there is a significant correlation between SDGs and CE indicators. Moreover, European Countries can achieve SDGs by fostering circular initiatives, considering $\mathrm{CE}$ as a favoured tool to reach sustainable development. 


\subsection{Stakeholders Internalization Within the Urban Transformation Process}

It is widely acknowledged that the success of urban transformations, and particularly those based on large construction or infrastructure projects, is strictly related to the overall success of the design process, which is in turn significantly influenced by the involved stakeholders' interests and concerns [53]. Hence, stakeholders assumed as individuals and organizations that are actively involved in the project, or whose interests may be affected as the result of project's execution or completion, could be regarded as one of the projects' significant uncertainty factors [54].

In line with recent research on urban water governance [55], the internalization of a broad base of key stakeholders within urban planning, leveraging on process innovation, has been recognized as a key factor to foster a transition in urban water infrastructure [56,57]. In the context of the Research Oriented Action Research approach [58], leveraging on a cyclic and iterative process, local actors have been: (i) identified, (ii) analysed, (iii) prioritized and (iv) engaged. Given the economic, social, cultural and environmental activities, both port and urban ones, occurring in the coastal strip, a list of existing and potential stakeholders, as well as any organization, has been identified. Local actors have been afterwards gathered in the "providers", "influencers", "users" and "governors" categories, that have in turn been analysed and prioritized according to "power" and "interest" criteria. Employing a Power-Interest Grid [59,60] allowed for the selection of a manageable number of stakeholders, while assuming a broad definition of the concept [39] and elaborating a Stakeholders' Map (Figure 4).

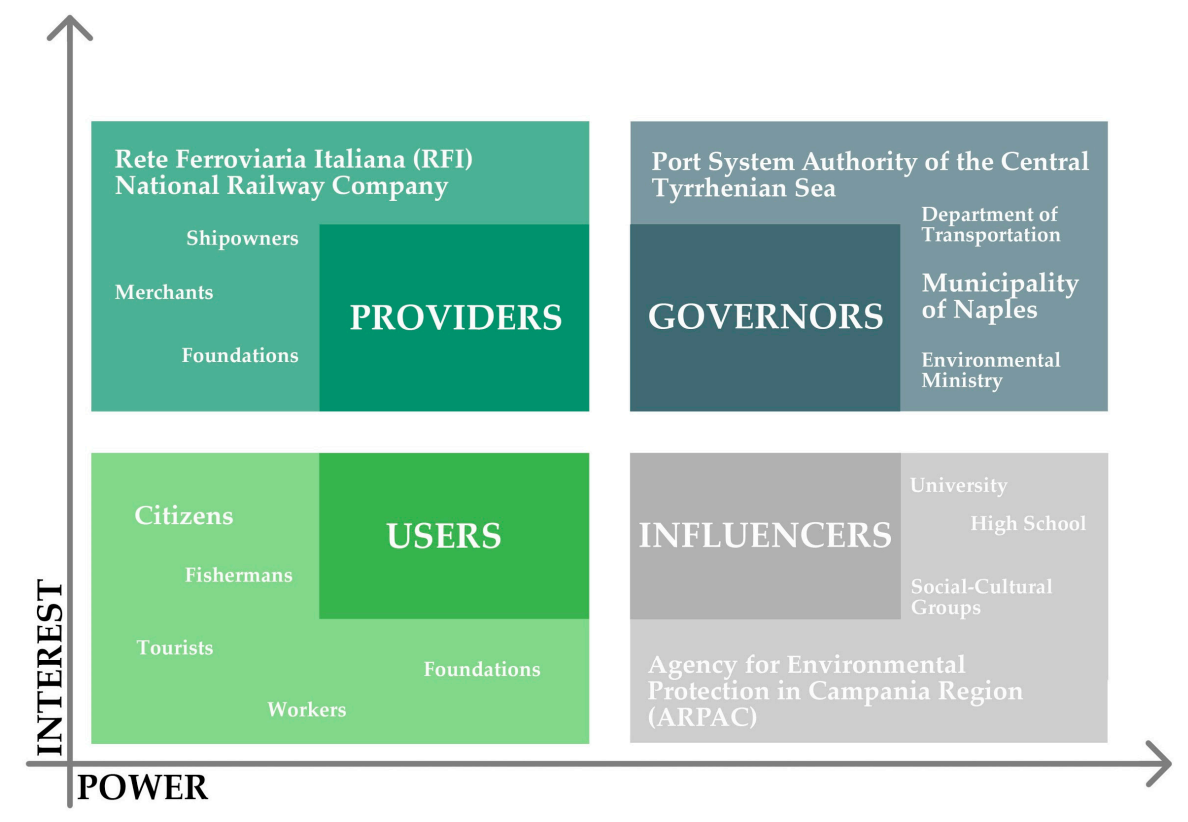

Figure 4. Stakeholders' Map (revised from Freeman, 1984).

In this map, "providers" and "governors" have been recognized as the two categories with the most relevant stakes, albeit with varying degrees of power. Indeed, whereas "governors" have a high degree of the results of the evaluation, "providers" have less influence. The lower categories, instead, were revealed as less interested. "Influencers" could exert a significant impact on policies affecting the future context, whereas "users" exhibit a low degree of interest in, or power to, influence the strategic outcomes. In order to involve local actors, within a stakeholder engagement approach [61], a series of theme-based focus groups have been held with the main institutional stakeholders, at the local scope currently in force. The viewpoints of different stakeholders have thus been collected as the input of knowledge at the base of the scenarios structuring process. Subsequently, with the aim of managing conflicting relationships, a stakeholder dialogue has been carried out to foster the interdisciplinary interaction between various actors [62-66]. 
In an open and respectful context, triggering processes of mutual responsibility and information-sharing [67], a multistakeholder dialogue fosters reciprocal engagement, understanding, and learning [62,68]. It has therefore been regarded as a vital component in the learning processes, due to its ability to co-construct ethical obligations and responsibilities [69]. The internalization of local stakeholders, allowing a more detailed knowledge framework structuring, has therefore oriented the overall collaborative planning process, in its implementing, operating and maintenance phases.

\subsection{Development Alternatives for the San Giovanni A Teduccio Port Area}

To define a sustainable development strategy for Naples' city-port system, plan forecasts provided by regulatory instruments currently in force, alongside some city-port regeneration best practices, have been analysed. More specifically, the project for the tourist port drawn by the Municipality of Naples in 1995, along with the master plan for the commercial port development identified by the Port System Authority of the Central Tyrrhenian Sea in 2018, and a freight railroad localization project proposed by the National Railway Company Rete Ferroviaria Italiana (RFI) have been considered. Starting from the combined analysis of regulatory instruments and good practices, within the multidisciplinary working group of the second-level Master in "Sustainable Design and Planning of Port Areas" of the Department of Architecture (DiARC) of the University of Naples Federico II, three different development strategies have therefore been defined (Figure 5) and presented to local stakeholders.

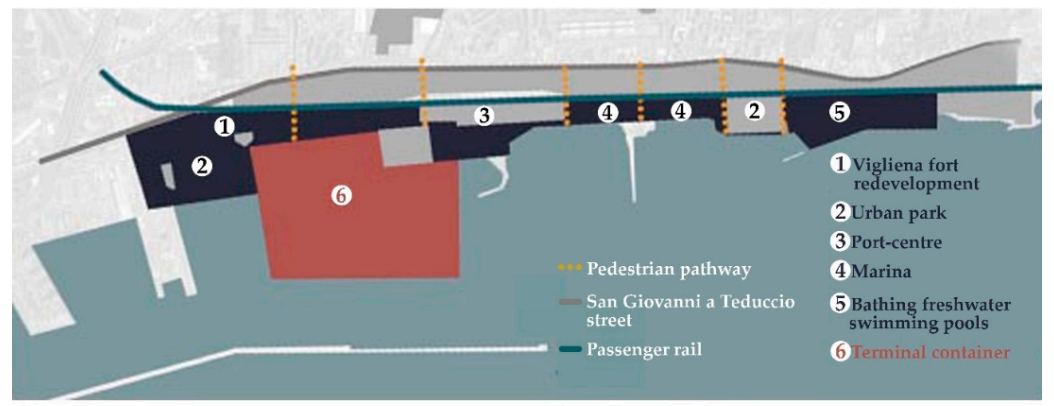

[A1] - Alternative 1 - Touristic Harbour (TH)

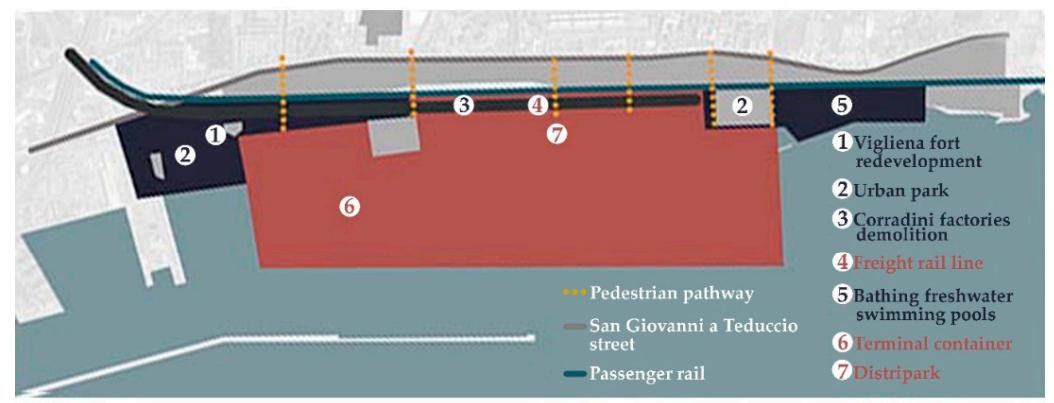

[A2] - Alternative 2 - Commercial Harbour (CH)

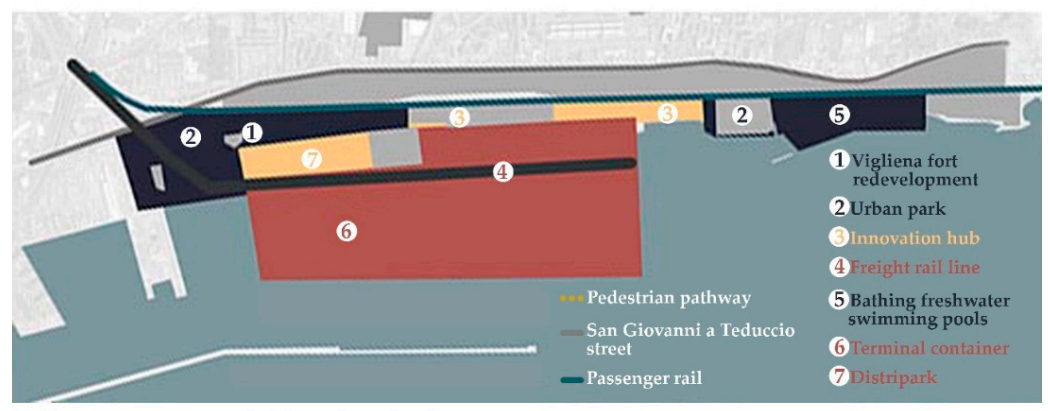

[A3] - Alternative 3 - Hybrid Harbour (HH)

commercial

hybrid

Figure 5. Three development alternatives for the San Giovanni port area. 


\subsubsection{Alternative 1: Tourist Development (A1)}

Assuming tourist development as a goal for the San Giovanni a Teduccio port area regeneration, a strategic vision, called "A1", has been elaborated. More specifically, in order to establish the conditions for sustainable tourism, a regenerative strategy based on tourist development combined with urban functions has been pursued. In this perspective, a set of actions aiming at structuring an environment permeable to both tourist and local flows has been proposed. Based on the individuation of historic buildings and roads regarded as crucial in reconnecting the coast to the city, the intervention area can be divided into six sectors, for each of which a strategic action has been identified. The redevelopment of the Vigliena Fort and its bordering area, currently abandoned, and the subsequent creation of an urban park, have been assumed. The already completed refurbishment of the former Cirio factory, which currently hosts the San Carlo laboratories, could be regarded as the starter for the redesign of the area within a circular perspective. In this context, a refurbishment has also been planned for the ex Corradini factory. The industrial archaeology plant on which the Superintendence of Cultural Heritage has recently placed a restriction would host a port-centre, i.e., an educational and exhibition centre to promote and spread the knowledge of the activities taking place in the port among the local population.

Within the buildings of the former industrial complex, commercial activities related to local handicraft and agricultural production, as well as those of a tertiary nature, would also be located. For the stretch of coastline between the ex Corradini factory and the treatment plant, which is now almost completely abandoned, there is the plan to build a marina, which can also serve as a sea taxi stop. Immediately to the east of that stretch of coast, there is the treatment plant for which the recently approved planning tools foresee the relocation to another area in the eastern part of Naples. On the area in which it is located, the construction of a city park has been planned. Finally, in the stretch between the treatment plan and the nearby Pietrarsa Railway Museum, in response to a demand for land use made manifest, even though informally, by the local citizens, the construction of freshwater swimming pools is expected. Levante Dock, for which infrastructure adaptation works have been planned, will be used as terminal container. The areas immediately adjacent to the Tirreno power plant and located north of the Levante Dock will serve the terminal container. A system of pedestrian and cycle paths was designed to reconnect San Giovanni a Teduccio Street with the coastline, bypassing the historic railway line which has launched a gradual and pressing detachment of the city from the coast. In order to improve the accessibility of the area, the reorganization of the vehicular traffic has also been planned, along with the construction of new parking areas and the strengthening of public transport. In this context, it is expected that the new functions allocated to the main urban landmarks found in the area will act as attractors, and therefore catalysts for flows.

\subsubsection{Alternative 2: Commercial Development (A2)}

Another strategic vision proposed for the regeneration of the area is based on the commercial development of the port, which has been identified as "A2". Following the planning guidelines provided by the Port System Authority of the Central Tyrrhenian Sea, the extension of the terminal container to obtain a $1.8 \mathrm{~km}$ long quay is expected. The areas immediately adjacent to the Tirreno power plant and located north of the Levante Dock will serve the terminal container. The demolition of the former Corradini factory and the subsequent construction of the freight rail line close to the quay, as proposed by the National Railway Company RFI, are thus envisaged. Implementing plan forecasts as part of the strategic vision is intended to encourage the establishment of companies and manufacturing enterprises, to boost economic production both at the local and territorial levels. Within an integrated and cross-scale perspective, a strategy pivoting on the commercial development of the port combined with commercial and tertiary urban functions has thus been pursued. East of the Tirrenia power plant, a "distripark" has been planned. Composed of "distribution" and "park", this name refers to an integrated logistics hub for storage, manufacturing, quality control and distribution of goods-more specifically, freight containers. Aiming to redevelop the Vigliena Fort and the surrounding area, an urban park has been projected. The stretch of coastline between the former Corradini factory and 
the treatment plant is instead intended to be used as an outdoor equipped space belonging to the distripark. It is also forecast that the former treatment plant will be converted into an urban space, whereas the next stretch of coast, extending until the Pietrarsa Railway Museum, will host freshwater swimming pools. Finally, the reorganization of the pedestrian, cycle and vehicular crossings system is proposed in order to improve the accessibility of the area.

\subsubsection{Alternative 3: Hybrid Development (A3)}

Finally, in compliance with the Sustainability Development Goals (SDGs) provided by the United Nations in the Agenda 2030, within a multidimensional perspective, a further planning alternative leveraging on a hybrid development strategy, which has been identified as "A3", has been proposed. In this context, the draft plan aims at localizing both urban and commercial functions close to the coastline. The expansion of the commercial quay is therefore expected at $1.2 \mathrm{~km}$. The construction of the freight rail line close to the quay has been envisaged, albeit with a different route from that proposed by the National Railway Company RFI. The areas immediately adjacent to the Tirreno power plant and located north of the Levante Dock will be used as a distripark. The former Corradini factory would host an innovation hub, whose activities, based on digital innovation, would trigger connections for manufacturing industries, service industries and research. The stretch of coast between the former abandoned industrial complex and the treatment plant is intended as an outdoor equipped space belonging to the innovation hub. For the redevelopment of the areas currently occupied by the Vigliena Fort, the treatment plant and the subsequent stretch of coast, extending to the Pietrarsa Railway Museum, the previously described interventions are proposed. Finally, the reorganization of the pedestrian, cycle and vehicular crossings system is identified in order to improve the accessibility of the area.

\section{Results}

\subsection{Role-Playing Simulation for the San Giovanni a Teducci Neighbourhood: A Bottom-Up Approach}

The Role-Playing Game (RPG) consists of techniques and methods engaging stakeholders in collaborative decision-making and actions, simulating scenarios in which participants can choose to interpret different roles and fostering critical thinking and the intrinsic motivation of the involved people [70]. Such methods allow citizens to become more aware of the main issues and implications of planning and design processes, within conflicting perspectives and interests, enhancing communication and rationality in decision-making [38]. Indeed, RPG should support local communities and stakeholders in dealing with complex situations, as well as improve the learning contents and facilitate debates about the real-world environmental, social and economic transformations of the neighbourhood [71]. Nonetheless, the simulation process, through which participants become characters and play a role, constitutes as an abstraction of reality. Ryan [72] has demonstrated that the players attach real-life values to RPG outcomes and trigger knowledge exchanges also beyond the playground.

The primary outcome of RPG has been focused on putting the designers and their ideas in the context of social change, so that the interaction with citizens living in the district could address more circular and sustainable design actions [73]. In this study, RPG has been used to evaluate opportunities and threats of the three above-mentioned alternatives for the commercial port development and urban waterfront of the San Giovanni a Teduccio neighbourhood.

The operational purpose of the game has been to obtain the preference order of the alternatives and compute the scoring of the participants' judgements.

The simulation has been performed in the district of San Giovanni a Teduccio, at a theatre named NEST, which has represented, for ten years, a relevant point of cultural and social aggregation for the residents. Twelve people have been engaged in the game and, thus, the same number of relevant 
actors has been selected from the four categories of the Stakeholders' Map (Figure 4). The selected stakeholders are the following:

- The president of the Port System Authority of the Central Tyrrhenian Sea (ADSP);

- The Mayor of Naples;

- The president of a cultural association;

- The president of the National Railway Company;

- The president of the Agency for Environmental Protection of the Campania Region (ARPAC);

- The president of CONATECO (ship-owner);

- The director of the Apple Academy in San Giovanni a Teduccio neighbourhood;

- The president of the Tirrenia power factory;

- Tourist 1;

- $\quad$ Tourist 2;

- A journalist;

- A citizen.

A set of rules has been conceived by the promoters and conveyed to all the participants. The RPG lasted a total of an hour and thirty minutes divided into three time steps. The first time step-lasting five minutes-consisted in the explanation of the game's rules and the presentation of the main interests and purposes of each selected stakeholder; the second time step-lasting one hour-consisted in carrying out the game; while the third time step-lasting twenty minutes-led to the discussion and judgements aggregation. In a nutshell, the simulation has been focused on the following rules:

- Having the participants sit in a circle;

- Electing two facilitators with the task of moderating the discussion and reporting the results on a board;

- Asking participants to choose one role to be interpreted among eight selected stakeholders;

- Starting the first game round by having each participant declare at least three potentials and critical aspects in pursuing the three scenarios;

- Encouraging participants to express their agreement or disagreement with each alternative through the Likert scale, ranging between 1 to 5 -where 1 represents "strongly disapproving" and 5 means "strongly approving", while 3 expresses indecisiveness;

- Stimulating a final debate in order to foster new ideas.

The results showed a convergence of preferences towards Alternative 1-Tourist Port and Alternative 3-Hybrid Port, which respectively reached 34 and 36 scores. This means that the participants have felt the strong need for economic development and public services in the neighbourhood. Furthermore, they imagined, through these alternatives, potentialities of urban regeneration not only for the harbour, but also for the surrounding urban fabrics.

Finally, Alternative 2-Commercial Development has scored low, since the players perceived strong economic interests for harbour operators and few benefits for citizens and the city. Moreover, they were concerned about environmental costs such as urban congestion, marine and air pollution, waterfront abandoning and the further closure of the sea view from the mainland.

The RPG implementation was also useful to activate a collaborative process in the San Giovanni a Teduccio neighbourhood, involving and engaging the citizens in the decision-making process in order to improve the awareness level for the different issues related to the district regeneration and its relationship with the port area. The results of the RPG were relevant for the identification of preferences and the assessment of the alternatives, and for stimulating San Giovanni a Teduccio's inhabitants to promote local cooperation for their neighbourhood. 


\subsection{The PROMETHEE Method For Top-Down Evaluation and Scenarios Analysis}

Since strong conflicting values and interests among stakeholders coexist, and the decision-making problem needs to be structured involving multiple criteria, an optimization method that allows for the resolution of complex problems has been chosen. The best-fit multicriteria method to achieve single and global preferences of alternatives within this type of decisional environment consists of an outranking method. Therefore, the Preference Ranking Organization Method for Enriched Evaluation (PROMETHEE) has been adopted to elicit the alternative which outranks the others through a pairwise comparison procedure. It also sets the preference, indifference and incomparability thresholds among alternatives with respect to each criterion $[74,75]$.

As mentioned above, the set of selected criteria corresponds to the Sustainability Indicators (Table 1), which have been used as proxies to measure sustainability and circular economy values.

Moreover, applying PROMETHEE to real-world cases allowed for the quantification of how much one alternative outranks the others according to the main institutional stakeholders' preference degree, to select a compromise solution.

Problem formulation and outcomes have been achieved through the open-source software referred to as Visual PROMETHEE [53]. Four scenarios have been produced, taking into account the visions of the most influential stakeholders engaged, which are:

- Port System Authority;

- Municipality of Naples;

- National Railways Company (RFI);

- Environmental Protection Agency (ARPAC).

Since it has not been possible to elicit precise weights per each criterion with respect to the alternatives, the assessment has been performed by setting the preference functions and threshold values according to the position of each stakeholder with respect to the five domains and related indicators per each alternative. The stakeholders' visions have been inferred from public debates, lectures and focused meetings during the second-level Master's course. The results show that Alternative 3 outranks the other in all the four scenarios, reaching positive scores both in the net outranking flows (Figure 6) and in the aggregated flows visualization (Figure 7).

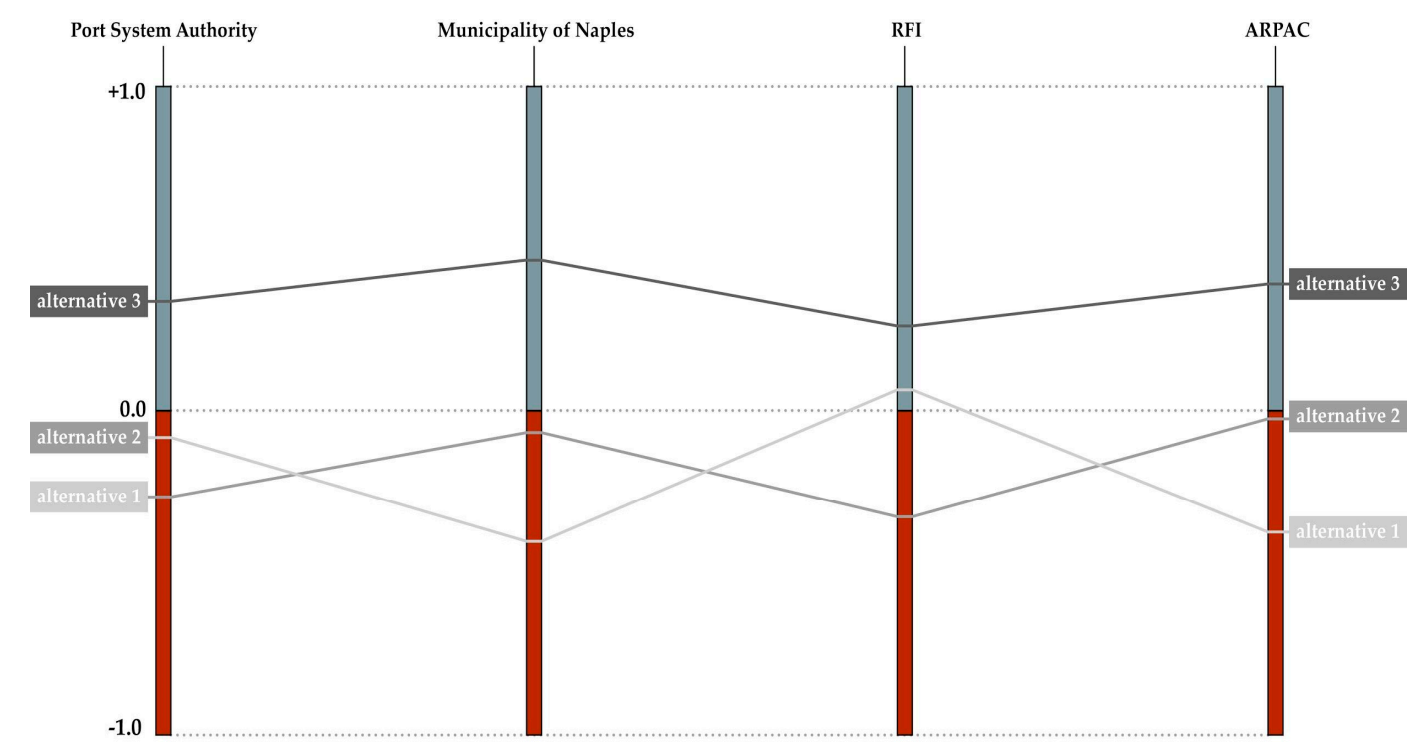

Figure 6. Net outranking flows diagram related to the scoring of three alternatives with regard to the four scenarios. 


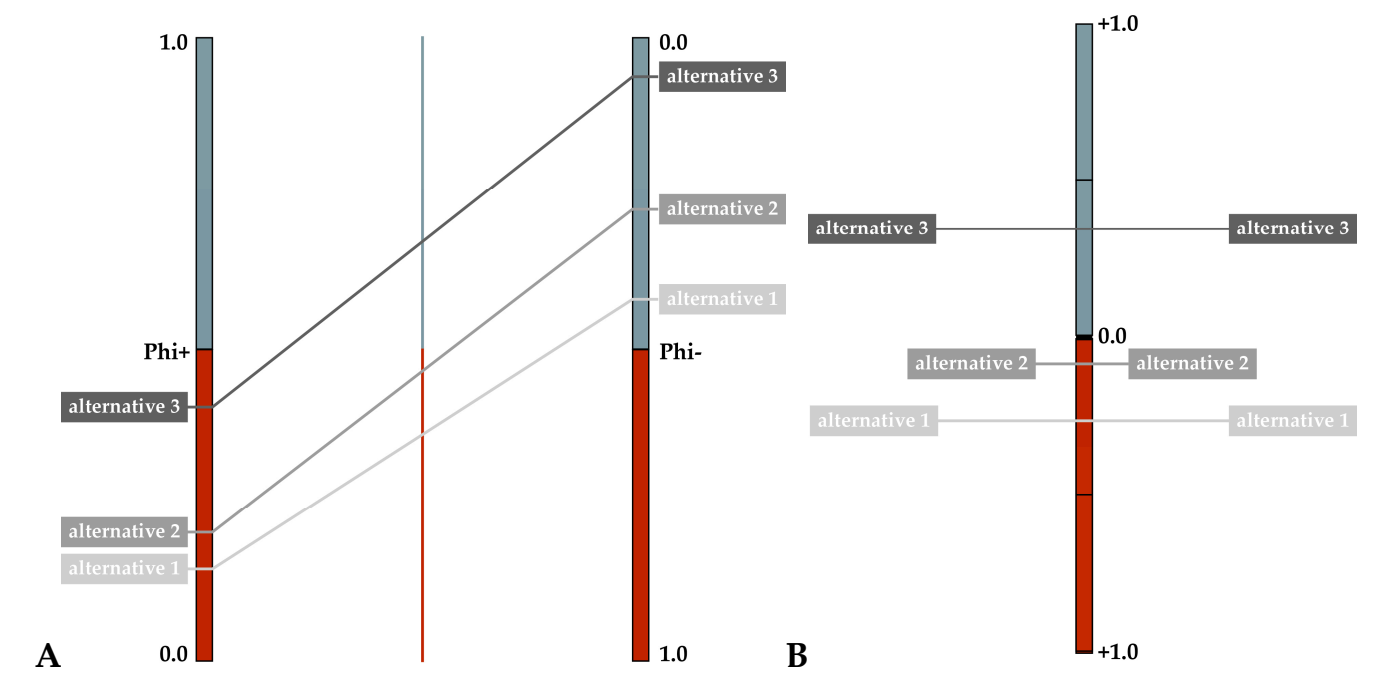

Figure 7. Preference Ranking Organization Method for Enriched Evaluation (PROMETHEE) II outranking flows. Uni-criterion positive flow $(\mathrm{f}+)$ and uni-criterion negative flow $(\mathrm{f}-)(\mathbf{A})$; net outranking complete flow as subtraction of negative flows from positive ones (B).

The bar chart in Figure 8 allowed for the quantitative definition of the criteria which determine the opportunities and threats for the A1, A2 and A3 alternatives (Figure 8). Alternative 3 maximizes four of five criteria belonging to the Society and Culture (SC), Urban Landscape Quality (ULQ) and Economic Growth and Development (EGD) dimensions, while the Urban Metabolism (UM) dimension is located in the negative quadrant, also in Alternative 2. This means that almost all the stakeholders expect a worsening of the air quality index (UM1), which is supposedly correlated with the extension of the dock and the increase of big ship berthing. The positive flows of the other indicators compensate for this critical issue, related to UM in Alternatives 2 and 3. Finally, the GAIA plane shows the similarities between the alternatives and opportunities/threats of each option, depicting the criteria as lines and the alternatives as dots.

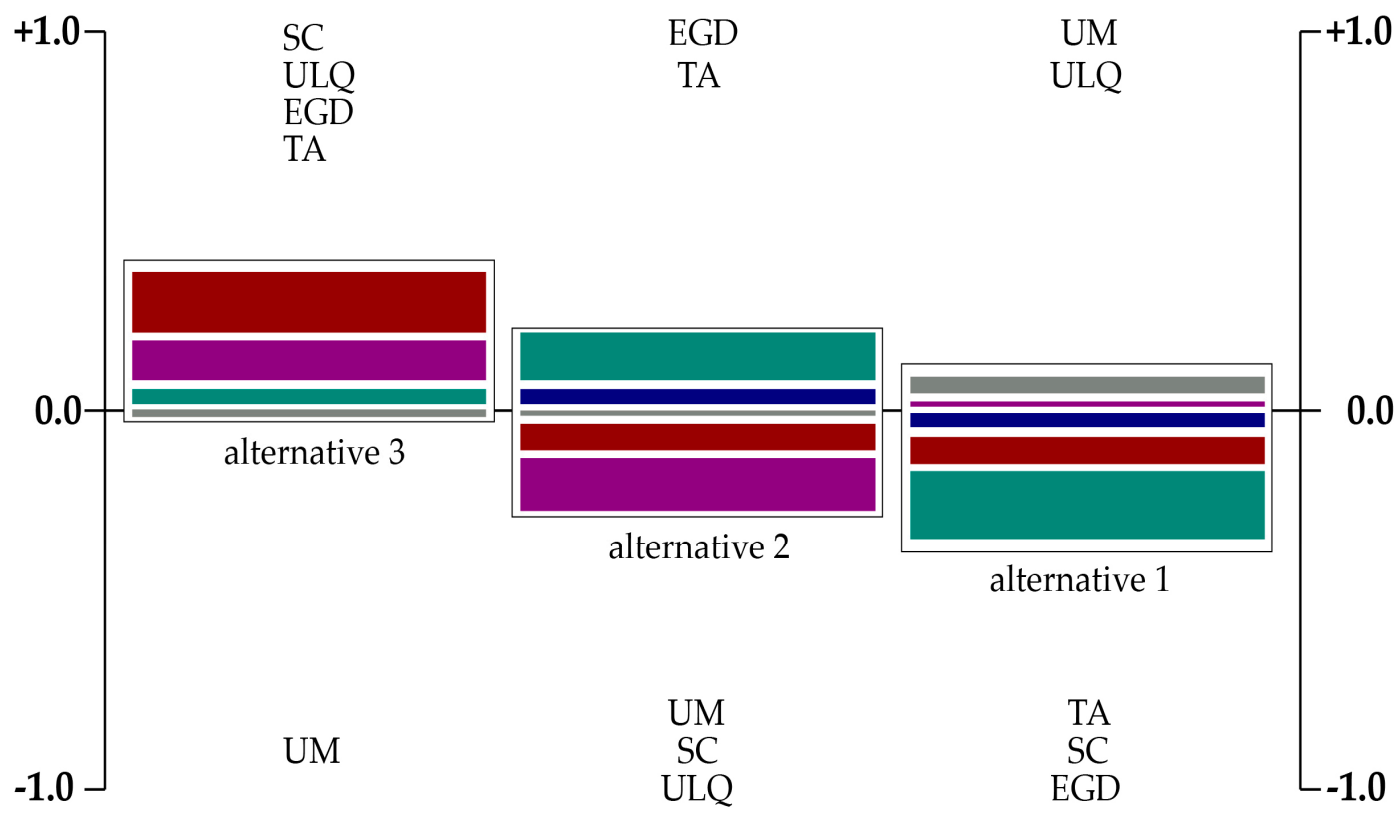

Figure 8. Bar chart of criteria: opportunities and threats for the A1, A2 and A3 alternatives.

The spatial distribution of criteria in the Euclidean space of the plane allows for the evaluation of the concordance among criteria, in order better to visualize conflicts or synergies (Figure 9). In the 
GAIA plane, it is evident that Alternative 3 is positioned in the same quadrant as the Decision Axis, that is, the projection of the weight vector (Decision Stick) on the GAIA plane. Indeed, Alternative 3 fosters synergies among criteria, with specific attention to the domains of Economic Growth and Development (EGD) and Society and Culture (SC), trying to reduce social, environmental and economic conflicts among the main stakeholder's scenarios. Taking into account the different rankings' results, the bar chart of criteria and the GAIA plane's configuration, and by observing the values of global flows per each alternative, the best-fit scenario is related to Alternative 3-Hybrid Development. This alternative has been assumed as a guideline for the master plan drawing, and as a basis for the elaboration of the subsequent steps of the decision-making process.

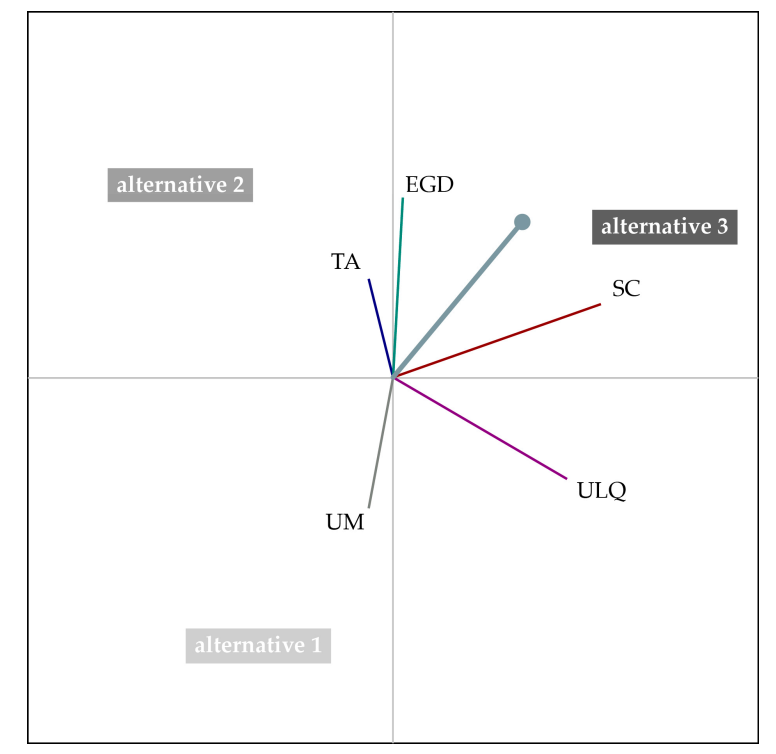

Figure 9. GAIA plane: A1, A2 and A3 alternatives and synergies among criteria.

\subsection{San Giovanni a Teduccio's Development Strategy: the Master Plan}

Within the interdisciplinary second-level Master's working group, the hybrid development strategy has been further developed, up to the master plan definition (Figure 10). According to the aim of reconnecting the urban fabric to the coastline, assuming the urban layout as the project grid, the localization of new attractive centralities-some of which in the location of pre-existing urban landmarks - has been expected, alongside the construction of driveway, pedestrian, cycle, rail and port accessibility systems. The master plan concept leverages the realization of a filtering area both uniting and separating urban and port functions through an infrastructure in which nature and construction coexist. The project area is developed along San Giovanni a Teduccio Street, including both some enclosed areas in the urban fabric and the coastline. Behind the facade of buildings overlooking San Giovanni a Teduccio Street, largely residential, a passenger railway station served by areas used for interchange parking have been planned. Beyond the area of the passenger railway, developing along the ancient Naples-Portici railway line, urban functions are expected. In addition to urban functions, the project includes a series of interventions also attributable to port and hybrid functional macrocategories. Below is a more detailed description. Starting from the left, close to the former Cirio factory, recently redeveloped and currently used for the San Carlo theatre's laboratory activities, an inner harbour area with a distripark is envisaged in order to support all the activities related to logistics, rail gateway, import and export.

Alongside the redevelopment of the ancient Vigliena Fort, the demolition of some residential buildings found in the area and the reconstruction with the same functional purpose, as well as the creation of an urban park, have been planned. The ensuing stretch of coast has instead been intended for tertiary activities. For the adjacent complex of buildings known as the former Corradini 
factory, redevelopment work with the settlement of an innovation hub has been envisaged. Including both working spaces and research centres, it is believed that hubs enable active knowledge transfers between researchers and business experts, on the one hand, and industry, government and academia representatives, on the other hand. The above-mentioned innovation hub has been designed, moreover, as part of a new local network. Indeed, the Apple Academy, a centre of innovation in research and the industrial field, is already situated within the urban fabric, and more specifically in the seat of the Federico II University of Naples. An innovative function has also been expected in the building placed on the upper side of the terminal container, facing the channel that separates the urban area from the port area. The building, connected to the coastal strip through a system of pedestrian crossings, as well as cycle paths, develops along the edge of the terminal container and arranges spatial flows-welcoming urban flows, while separating them from trade port ones.

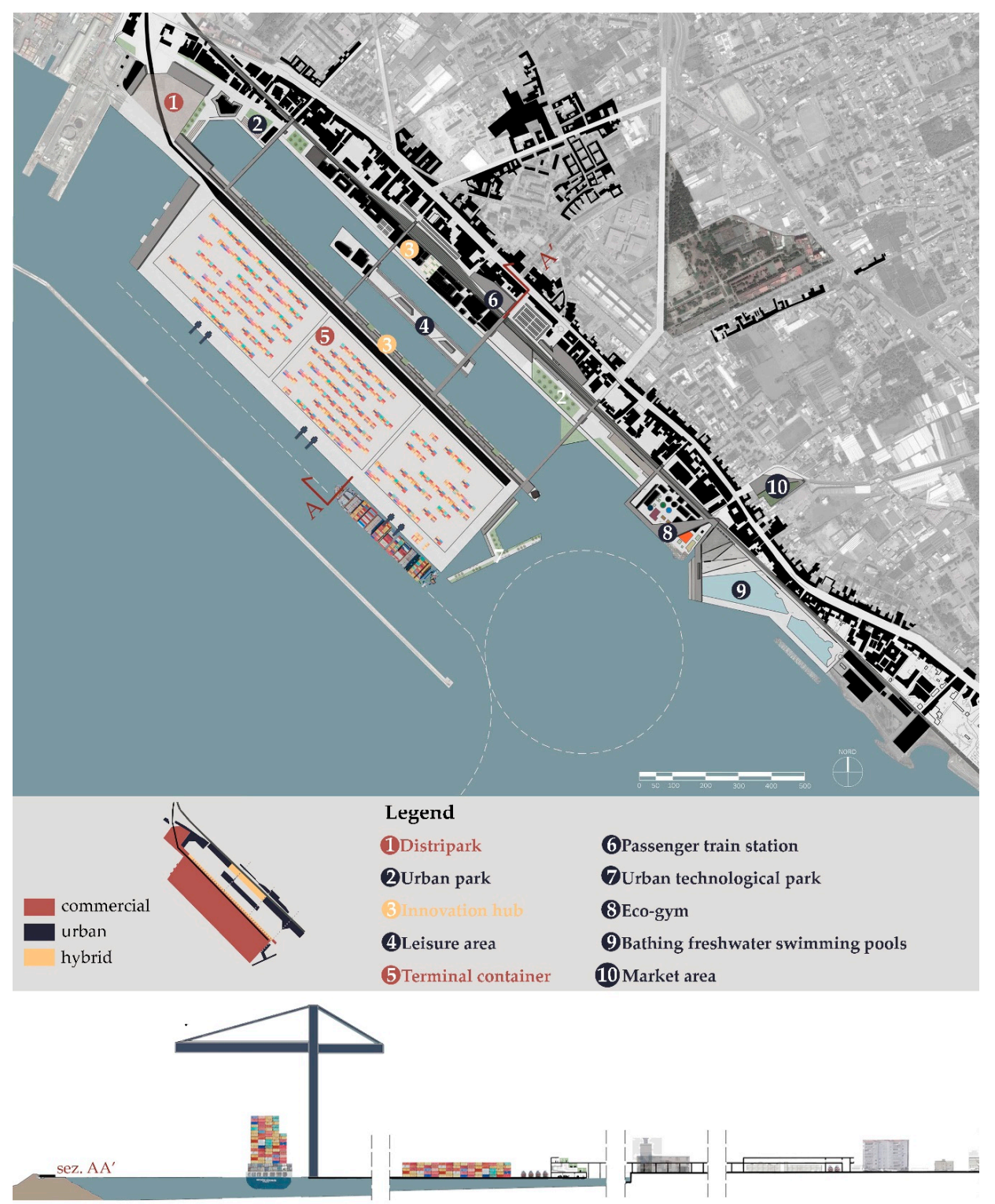

Figure 10. San Giovanni a Teduccio's development strategy: the master plan.

As part of the filtering area, located in front of the former Corradini factory, the Tirreno power plant maintains its localization, although its access system has been significantly modified due to the new configuration of the coastline as per the blueprint. Immediately to the east of the power plant, a leisure area that extends until the stretch of coast between the former Corradini factory 
and the former treatment plant has been planned. Not far from there, we find the already existing Massimo Troisi park, within the urban fabric, as well as the urban technological park on the right side of the terminal container, according to a preview of the plan. Moving eastward, we come across the former treatment plant, whose demolition and redevelopment interventions have also been planned. Further along, the creation of an eco-gym is expected, an outdoor space provided with equipment capable of converting kinetic energy deriving from gymnastic movement into electrical energy. In the successive stretch of coast between the former treatment plant and the current Pietrarsa Railway Museum, in response to user requests arisen from the local population, the construction of freshwater swimming pools is expected. In the evening hours of warm seasons, the same structure is intended to be used also as an outdoor theatre. From there, located between the former treatment plant and the outdoor theatre, a market area with covered parking can be attained. The master plan also contemplates the construction of infrastructures in support of trade port functions, and the expansion of the commercial quay is expected to be up to $1.2 \mathrm{~km}$ in length. In order to facilitate cargo handling, in addition to the extension of the terminal container, the quay is to be equipped with a lookout tower and a devoted freight railway

\section{Discussion}

The adaptive and multimethodological decision-making process for the development of strategies for Naples' city-port has made it possible to identify the significant components that can influence place-based choices, with attention to the specific reality of the analysed context, in order to implement the CCM. The goal of the methodological path-processing an integrated methodology to define and evaluate new solutions for a circular city-port, joining hard and soft knowledge-was implemented by combining a multidimensional evaluation approach, the selection of SIs and the development of the Stakeholders' Map.

Among the four operational steps that characterize the process, the first, problem structuring, represents the most complex one, in which the premises of the decision-making process were built and the dynamics that influenced the choices were explored. In this phase, the existing conflicting issues were analysed, the SIs were chosen within the SDGs domains, the Stakeholders' Map and the stakeholders' internalization process were elaborated and the decisional flows were identified. In particular, the selection of the indicators with which to analyse the city-port system and evaluate the impacts of the intervention alternatives has made it possible to integrate the SDGs with the SIs, taking into account both the categories relevant to the issues consistent with the general objectives of the process and the specificities of the context, identifying place-based indicators useful for describing how to make the CCM operational. The selection of the relevant domains (Economic Growth and Development, Traffic Accessibility, Urban Metabolism, Society and Culture and Urban Landscape Quality) and the related indicators have made it possible to structure an evaluation matrix with which to analyse the critical areas and potential of the study area and, subsequently, to verify the impacts determined by the three alternatives.

In the second operational step, defining alternatives, the interaction between multidisciplinary skills (planning, urban design, port infrastructure engineering, transport and logistics, hydraulics and urban economy) allowed for the identification of three main alternatives of transformation and regeneration of the area under examination, highlighting the different opportunities that each is capable of generating and, at the same time, how to resolve both urban and territorial critical issues. In this phase, the identification of the project actions that make up each alternative was particularly significant because it allowed for the comparison and interaction of different forms of knowledge, identifying win-win potentials.

In the third operational step, the evaluation of alternatives made it possible to integrate the bottom-up approach with the top-down one, taking into account feedback deriving from each one, capable of improving the technical evaluation and the social evaluation. The technical assessment was developed through a multicriteria analysis, using the PROMETHEE method, and was structured in 
order to take into account the criteria and indicators selected in the first operational step, but also to bring together the points of view of the main stakeholders, in an attempt to identify opportunities for coalitions and alliances.

The social assessment was carried out using the RPG approach, which made it possible to make explicit the key role of the interaction with stakeholders and to verify the need to accompany the decision-making process with constant opportunities for discussion and integration between interests and skills, to reach a shared vision which reflects the needs of the players involved, their ability to influence the decision-making process and to become an active and proactive part of the territorial transformations.

In the fourth step, the preferences comparison made it possible to integrate the PROMETHEE method with the RPG approach, analysing, with the former, the impacts of the alternatives with respect to the domains of the selected SDGs and identifying, with the latter, the scoring attributed by the main stakeholders of the decision-making process (Port System Authority; Municipality of Naples; National Railways Company (RFI); Environmental Protection Agency (ARPAC)). The results of this phase have allowed for the outlining of the actions that characterize the master plan, in which the CCM strategy becomes operational, highlighting how the interventions represent not only an opportunity for urban and territorial regeneration, but also a way to activate a process of collaborative engagement and involvement among the different stakeholders.

The contribution outcomes have been centred on the assessment of three design alternatives for the East Naples port and the development of a hybrid regeneration scenario consistent with CE and sustainability principles. The structured decision-making process has allowed us to test how an adaptive approach can expand the knowledge base underpinning policy design and decisions to achieve better outcomes and cultivate a broad civic and technical engagement, that can enhance the legitimacy and transparency of policies.

The main limitations of the proposed approach are to be found in the fact that the application of the process takes a long time (in our case it took about a year) and the involvement of different skills, willing to cooperate. Furthermore, the integration of hard and soft knowledge requires not only a careful collection and selection of data, useful for structuring appropriate indicators, but also an in-depth interaction with the various stakeholders, in order to consider and include, clearly and transparently, the specific points of view. Indeed, the decision-making process, taking into account the results of the different phases and the possible interactions between the different forms of knowledge, developed according to an adaptive approach, using the various contributions of the different steps to reformulate the path and identify the ways to manage the next one. Therefore, one of the most critical aspects of the decision-making process' repeatability lies in the ability to manage the different phases and to be able to obtain from each useful information to make the next operational.

Adaptive decision-making takes into account the complexity of interlinked social, technological, ecological and economic development relating to the contingency of human action in a context of long-term systemic change [76]. In this context, nonlinear, interdependent and pervasive processes entail the continuous monitoring and modulation of ongoing processes, with the revision of planning and policy tools and the recalibration of goals. Through this kind of experimentation, decision-makers can pragmatically appraise how various options perform in the field and thus draw on strategies that are appropriate to specific circumstances and tailored to unfolding developments [77].

The methodological proposal was useful to support the elaboration of the choices and the outlining of the decisions that the Port System Authority of the Central Tyrrhenian Sea (ADSP) and the Mayor of Naples are facing, opening a technical and social reflection on one of the most relevant regeneration issues currently being managed in the city.

\section{Conclusions}

According to COTER [19], to ensure the sustainable development of port-cities, it is necessary to adopt innovative and integrated solutions which are in line with the principles of urban development 
in the EU, taking into account the economic, social and environmental aspects of these places. In this context, the paradigm of CE [78-81], when it is applied to cities, becomes a key factor in reviewing development processes $[6,10,82-84]$. At the same time, the $\mathrm{CE}$ can be a suitable paradigm to respond to the sustainability challenges faced by harbours-on the one hand, guaranteeing their competitiveness in a world of limited resources, and on the other hand promoting innovation, reducing environmental impacts and redefining city-port relationships and boundaries [84-87]. The CE in harbours can represent a synergistic process that combines economic, logistic and industrial activities with the cultural and social heritage of the ports and the creativity of their communities, generating a dynamic, complex and sustainable system. Indeed, in port-cities the development model provided by circular cities fosters an original balance between different objectives and purposes, maximizing port efficiency and productivity, optimizing the city impacts in terms of employment, environmental conditions and quality of life, and combining microeconomic and macroeconomic purposes [87,88]. Within the Integrated Maritime Policy of the European Union [19,20,28], Maritime Spatial Planning is identified as a central tool for managing coastal areas and maritime governance, recognizing planning as a decision-making process and as a cross-sectoral political tool that allows public authorities and stakeholders to apply an integrated, coordinated and cross-border approach. Through the Maritime Spatial Planning process, within a coherent and transparent decision-making framework, able to take into account the multidimensional, multiactor and multidisciplinary nature of the port system, it is intended to implement appropriate policies for city-port sustainable development. Incorporating evaluation methods, able to combine top-down and bottom-up approaches into adaptive decision-making and governance processes is a crucial point, which can be essential for identifying change in a transition context. An adaptive approach becomes flexible to meet the challenge posed by that change and enable progressive and mutual learning on the individual, community, institutional and policy levels, while seeking to overcome the substantial gap between theory and practice $[36,88]$. At the same time, the CE, as a relevant topic for the city-port future, recognizes environmental and sustainable values as essential to support the transition.

In this perspective, Maritime Spatial Planning can support the implementation of CCM, expression of the circular city-port, characterized by high connectivity and smart infrastructure, enabling high-quality services with a low environmental footprint, good city design, sustainable lifestyles, empowered local actors and participatory approaches [27]. This approach implies the need for a different governance, capable of developing long-term integrated and multidimensional shared sustainable development programmes, in which public institutions and the government work with active civil society members, researchers, entrepreneurs and NGOs $[10,44,89]$, where circular transition, as sustainable transition, requires a broader engagement, empowerment and breakthrough strategies, able to enable, facilitate and direct social innovation processes towards an adaptive and innovative urban future [90]. The city-port is the context where the different types of integration take place, and where it is possible to manage the circular transition, stimulating territorial productivity, economic development and social cohesion. In this perspective, the port authorities and the municipalities are therefore called to carry on with circular transformation operations and to build processes of dialogue and interaction between the different stakeholders, in order to guide and support the port's development in a perspective of recomposition and integration with the city.

Author Contributions: The authors jointly conceived and developed the approach and decided on the overall objective and structure of the paper. In particular, conceptualization and methodology, M.C.; formal analysis, investigation and validation, E.G.d.G.; methodology, software and validation, G.P.; investigation, data curation and software, S.R. The authors jointly contributed to the writing of the paper and have read and approved the final version.

Funding: This research received no external funding.

Acknowledgments: The research presented in this paper has been developed within the second-level Master in "Sustainable Design and Planning of Port Areas", Department of Architecture (DiARC), University of Naples Federico II, and it is part of the Italian research Project of Relevant National Interest (PRIN, 2015) "Metropolitan 
cities: territorial economic strategies, financial constraints, and circular regeneration", coordinated by the Polytechnic of Milan.

Conflicts of Interest: The authors declare no conflicts of interest.

\section{References}

1. European Commission. Urban Agenda for the EU Multi-Level Governance in Action; European Union: Brussels, Belgium, 2019.

2. Annoni, P.; Dijkstra, L. The EU Regional Competitiveness Index 2019; European Union: Luxembourg, 2019.

3. ENEL (Ente Nazionale Per L'energia Elettrica). Circular Cities Cities of Tomorrow, 1st ed.; ENEL: Rome, Italy, 2018; Available online: https://www.enel.com/content/dam/enel-com/media/document/cities-of-tomorrow_ en.pdf (accessed on 12 December 2019).

4. ENEL (Ente Nazionale Per L'energia Elettrica). Circular Cities Cities of Tomorrow, 2nd ed.; ENEL: Rome, Italy, 2019; Available online: https://corporate.enel.it/content/dam/enel-it/media/documenti/circular-cities-citiesof-tomorrow_en.pdf (accessed on 12 December 2019).

5. Eurocities. Full Circle, Cities and the Circular Economy; Eurocities: Brussels, Belgium, 2017.

6. Ellen MacArthur Foundation. Circular Economy in Cities: Project Guide; Ellen MacArthur Foundation: Cowes, UK, 2019; Available online: https://www.ellenmacarthurfoundation.org/assets/downloads/CE-in-CitiesProject-Guide_Mar19.pdf (accessed on 12 December 2019).

7. Fusco Girard, L.; Nocca, F. Moving towards the Circular Economy/City Model: Which Tools for Operationalizing This Model? Sustainability 2019, 11, 6253. [CrossRef]

8. Fusco Girard, L. Toward a Smart Sustainable Development of Port Cities/Areas: The Role of the Historic Urban Landscape Approach. Sustainability 2013, 5, 4329-4348. [CrossRef]

9. Jonker, J.; Montenegro Navarro, N.; Circular City Governance. An Explorative Research Study into Current Barriers and Governance Practices in Circular City Transitions across Europe. Available online: https: //circulareconomy.europa.eu/platform/sites/default/files/circular-city-governance-an-explorative-researchstudy-into-current-barriers-and-governance-practices-in-circular-city-transitions-across-europe-2018.pdf (accessed on 12 December 2019).

10. Prendeville, S.; Cherim, E.; Bocken, N. Circular Cities: Mapping Six Cities in Transition. Environ. Innov. Soc. Transit. 2018, 26, 171-194. [CrossRef]

11. Bonato, D.; Orsini, R. Chapter 12-Urban Circular Economy: The New Frontier for European Cities' Sustainable Development. In Sustainable Cities and Communities Design Handbook, Green Engineering, Architecture, and Technology, 2nd ed.; Clark, W.W., Ed.; Elsevier: Amsterdam, The Netherlands, 2018; pp. 235-245.

12. Hein, C. Port Cities: Dynamic Landscapes and Global Networks, 1st ed.; Routledge: Milton Park, UK, 2011.

13. Hein, C. Adaptive Strategies for Water Heritage: Past, Present and Future; Springer: Cham, Switzerland, 2020.

14. Geissdoerfer, M.; Savaget, P.; Bocken, N.M.P.; Hultink, E.J. The Circular Economy-A new sustainability paradigm? J. Clean. Prod. 2017, 143, 757-768. [CrossRef]

15. Clemente, M.; Demarco, D.; Giovene di Girasole, E. Rigenerazione delle città dal mare per una crescita sostenibile. J. Urban. 2013, 2, 27, Planum. Available online: https://issuu.com/planumnet/docs/atti_xvi_ conferenza_siu_by_planum_n_7aa5cfb636d6dc (accessed on 20 December 2019).

16. Clemente, M. Città Dal Mare, L'arte Di Navigare E L'arte Di Costruire Le Città; Editoriale Scientifica: Napoli, Italy, 2011.

17. Ducruet, C. The port city in multidisciplinary analysis. In The Port City in the XXIst Century: New Challenges in the Relationship between Port and City; Alemany, J., Bruttomesso, R., Eds.; RETE: Venetia, Italy, 2011; pp. 32-48.

18. Hoyle, B.S. The Port-city Interface: Trends, Problems and Examples. Geoforum 1989, 20, 429-435. [CrossRef]

19. Commission for Territorial Cohesion Policy and EU Budge (COTER-VI/018). 121st Plenary Session, 8 and 9 February 2017, Opinion, Regeneration of Port Cities and Port Areas; European Committee of the Regions: Bruxelles, Belgium, 2017; Available online: http://edz.bib.uni-mannheim.de/edz/doku/adr/2016/cdr-20165650-en.pdf (accessed on 12 December 2019).

20. European Commission. Ports 2030, Gateways for the Trans European Transport Network; Communication from the Commission, $\operatorname{COM}(2013) 295$; European Commission: Brussels, Belgium, 2013; Available online: https://ec.europa.eu/transport/infrastructure/tentec/tentec-portal/site/brochures_images/ports2013_ brochure_lowres.pdf (accessed on 12 December 2019). 
21. Russo, M. Waterfront portuale. Paesaggi e potenzialità di uno spazio conteso/Harbour waterfront: Landscapes and potentialities of a con tended space. TRIA 2014, 7, 235-250.

22. Cerreta, M.; De Toro, P. Integrated Spatial Assessment (ISA): A Multi-Methodological Approach for Planning Choices. In Advances in Spatial Planning; Burian, J., Ed.; IntechOpen: Rijeka, Croatia, 2012; pp. 77-108. Available online: https://www.intechopen.com/books/advances-in-spatial-planning/integrated-spatial-assessment-isa-amulti-methodological-approach-for-planning-choices (accessed on 20 December 2019). [CrossRef]

23. Carta, M. Nuovo dividendo culturale per le politiche di sviluppo del Mediterraneo. Economia della Cultura 2016, 26, 57-62.

24. Fonti, L. Porti-Città-Territori. Processi Di Riqualificazione E Sviluppo; Alinea Editrice: Roma, Italy, 2010.

25. Bruttomesso, R. Waterfronts: A New Frontier for Cities on Water; Edizioni Città D'acqua: Venice, Italy, 1993.

26. Ellen MacArthur Foundation. Cities in the Circular Economy: An Initial Exploration; Ellen MacArthur Foundation: Sail Loft, UK, 2017.

27. TWI2050. The World in 2050. The Digital Revolution and Sustainable Development: Opportunities and Challenges; Report Prepared by the World in 2050 Initiative; International Institute for Applied Systems Analysis (IIASA): Laxenburg, Austria, 2019; Available online: www.twi2050.org (accessed on 20 December 2019).

28. European Parliament (EP). Directive 2014/89/EU of the European Parliament and of the Council of 23 July 2014 Establishing a Framework for Maritime Spatial Planning. 2014. Available online: http://eur-lex.europa. eu/legal-content/EN/TXT/?uri=uriserv:OJ.L_.2014.257.01.0135.01.ENG\%20 (accessed on 30 November 2019).

29. Cerreta, M.; Poli, G.; Regalbuto, S.; Mazzarella, C. A Multi-dimensional Decision-Making Process for Regenerative Landscapes: A New Harbour for Naples (Italy). In Computational Science and Its Applications-ICCSA 2019. ICCSA 2019. Lecture Notes in Computer Science; Misra, S., Gervasi, O., Murgante, B., Stankova, E., Korkhov, V., Torre, C., Rocha, A.M.A.C., Taniar, D., Apduhan, B.O., Tarantino, E., Eds.; Springer: Cham, Switzerland, 2019; Volume 11622, pp. 156-170.

30. European MSP Platform. Maritime Spatial Planning Country Information; EU MSP Platform: Venice, Italy, 2018; Available online: https://www.msp-platform.eu (accessed on 12 December 2019).

31. Sachs, J.; Schmidt-Traub, G.; Kroll, C.; Lafortune, G.; Fuller, G. Sustainable Development Report 2019; Bertelsmann Stiftung and Sustainable Development Solutions Network (SDSN): New York, NY, USA, 2019.

32. Wackernagel, M.; Hanscom, L.; Lin, D. Making the Sustainable Development Goals Consistent with Sustainability. Front. Energy Res. 2017, 5, 1-5. [CrossRef]

33. World Bank. Atlas of Sustainable Development Goals 2017: World Development Indicators; World Bank: Washington, DC, USA, 2017. [CrossRef]

34. Ministero delle Infrastrutture e dei Trasporti. Decreto Legislativo n. 201 del 17/10/2016. Attuazione Della Direttiva 2014/89/UE Che Istituisce Un Quadro Per La Pianificazione Dello Spazio Marittimo. Available online: https://www.normattiva.it/uri-res/N2Ls?urn:nir:stato:decreto.legislativo:20161017;201 (accessed on 12 December 2019).

35. Cerreta, M.; Concilio, G.; Monno, V. Making Strategies in Spatial Planning: Knowledge and Values; Springer: Berlin, Germany, 2010.

36. Cerreta, M.; Diappi, L. Adaptive Evaluations in Complex Contexts: Introduction. Ital. J. Reg. Sci. 2014, 13, 5-22. [CrossRef]

37. Jordan, A.J.; Turnpenny, J.R. The Tools of Policy Formulation: Actors, Capacities, Venues and Effects; Edward Elgar Publishing: Cheltenham, UK, 2015.

38. Boess, S.; Saakes, D.; Hummels, C. When is role playing really experiential? case studies. In Proceedings of the 1st International Conference on Tangible and Embedded Interaction, Baton Rouge, LA, USA, 15-17 February 2007; pp. 279-282.

39. Ackermann, F.; Eden, C. Strategic management of stakeholders: Theory and practice. Long Range Plan. 2011, 44, 179-196. [CrossRef]

40. Bana e Costa, C. Readings in Multiple Criteria Decision Aid; Springer: Berlin, Germany, 1990.

41. Mareschal, B. Visual PROMETHEE 1.4 Manual. 2013. Available online: www.Promethee-Gaia.Net (accessed on 20 September 2019).

42. Brans, J.P.; Mareschal, B.; Vincke, P. How to select and how to rank projects: The PROMETHEE method. Eur. J. Oper. Res. 1986, 24, 228-238. [CrossRef]

43. Berger, A. Drosscape: Wasting Land Urban America; Princeton Architectural Press: Hudson, NY, USA, 2007. 
44. Daamen, T. Sustainable development of the European port-city interface. In Proceedings of the ENHR-Conference, Rotterdam, The Netherlands, 25-28 June 2007; pp. 25-28.

45. Van de Ven, F.; Tjallingii, S.; Baan, P.; Van Eijk, P.; Rijsberman, M. Improving urban water management planning. In Proceedings of the International Symposium on Lowland Technology, Saga, Japan, 14-16 September 2006; pp. 573-578.

46. Cerreta, M.; Poli, G. Landscape services assessment: A hybrid multi-criteria spatial decision support system (MC-SDSS). Sustainability 2017, 9, 1311. [CrossRef]

47. Bonifazi, A.; Sannicandro, V.; Attardi, R.; Di Cugno, G.; Torre, M.C. Countryside vs. City: A User-Centered Approach to Open Spatial Indicators of Urban Sprawl. In Proceedings of the International Conference on Computational Science and Its Applications, ICCSA2016, Beijing, China, 4-7 July 2016; pp. 161-176.

48. United Nations (UN). Agenda 21. United Nations Conference on Environment \& Development Rio de Janerio, Brazil, 3 to 14 June 1992. Available online: https://sustainabledevelopment.un.org/content/ documents/Agenda21.pdf (accessed on 12 December 2019).

49. United Nations (UN). 66/288. The Future We Want. Resolution Adopted by the General Assembly on 27 July 2012. Available online: https://www.un.org/ga/search/view_doc.asp?symbol=A/RES/66/288\&Lang=E (accessed on 15 December 2019).

50. Hák, T.; Janoušková, S.; Moldan, B. Sustainable Development Goals: A need for relevant indicators. Ecol. Indic. 2016, 60, 565-573. [CrossRef]

51. Eurostat. Getting Messages across Using Indicators. A Handbook Based on Experiences from Assessing Sustainable Development Indicators; Eurostat: Luxembourg, 2014.

52. Rodriguez-Anton, J.; Rubio-Andrada, L.; Celemín-Pedroche, M.; Alonso-Almeida, M. Analysis of the relations between circular economy and sustainable development goals. Int. J. Sustain. Dev. World Ecol. 2019, 26, 708-720. [CrossRef]

53. Ward, S.; Chapman, C. Stakeholders and uncertainty management in projects. Constr. Manag. Econ. 2008, 26, 563-577. [CrossRef]

54. Rose, K.H. A Guide to the Project Management Body of Knowledge (PMBOK ${ }^{\circledR}$ Guide), Fifth Edition. Proj. Manag. J. 2013, 44, e1. [CrossRef]

55. Brown, R.R.; Clarke, J.M. Transition to Water Sensitive Urban Design: The Story of Melbourne, Australia; Facility for Advancing Water Biofiltration, Monash University: Melbourne, Australia, 2007; Volume 7.

56. De Graaf, R.; Van Der Brugge, R. Transforming water infrastructure by linking water management and urban renewal in Rotterdam. Technol. Forecast. Soc. Chang. 2010, 77, 1282-1291. [CrossRef]

57. Rijke, J.; Farrelly, M.; Morison, P.; Brown, R.; Zevenbergen, C. Towards improved urban water governance in Adelaide, Australia. In Proceedings of the 12th International Conference on Urban Drainage, Porto Alegre, Brazil, 11-16 September 2011; pp. 11-16.

58. Eden, C.; Huxham, C. Action research for the study of organizations. Br. J. Manag. 1996, 7, 75-86. [CrossRef]

59. Freeman, R.E. Strategic Management: A Stakeholder Approach; Pitman Publishing: Boston, MA, USA, 1984.

60. Freeman, R.E.; McVea, J. A stakeholder approach to strategic management. In The Blackwell Handbook of Strategic Management; Wiley: Hoboken, NJ, USA, 2001; pp. 189-207.

61. Greenwood, M. Stakeholder Engagement: Beyond the Myth of Corporate Responsibility. J. Bus. Ethics 2007, 74, 315-327. [CrossRef]

62. Burchell, J.; Cook, J. Stakeholder dialogue and organisational learning: Changing relationships between companies and NGOs. Bus. Ethics Eur. Rev. 2008, 17, 35-46. [CrossRef]

63. Danker, M. Understanding Stakeholder Activism, Managing Transparency Risk. In The Governance of Risk (Developments in Corporate Governance and Responsibility, Vol. 5); Crowther, D., Aras, G., Eds.; Emerald Group Publishing Limited: Bingley, UK, 2013; pp. 33-72. [CrossRef]

64. Esben Rahbek Pedersen, E.R. Making Corporate Social Responsibility (CSR) Operable: How Companies Translate Stakeholder Dialogue into Practice. Bus. Soc. Rev. 2006, 11, 137-163. [CrossRef]

65. Van De Ven, A.H.; Poole, M.S. Alternative approaches for studying organizational change. Organ. Stud. 2005, 26, 1377-1404. [CrossRef]

66. Nared, J.; Bole, D. (Eds.) Participatory Research and Planning in Practice; Springer: Berlin, Germany, 2020.

67. Waddock, S. Integrity and mindfulness: Foundations of corporate citizenship. In Perspectives on Corporate Citizenship; Andriof, J., McIntosh, M., Eds.; Greenleaf Publishing: Sheffield, UK, 2001; pp. 25-38. 
68. Burchell, J.; Cook, J. CSR, Co-optation and Resistance: The Emergence of New Agonistic Relations Between Business and Civil Society. J. Bus. Ethics 2013, 115, 741-754. [CrossRef]

69. McNamee, S.; Gergen, K.J. (Eds.) Relational Responsibility: Resources for Sustainable Dialogue; Sage Publications, Inc.: Newbury Park, CA, USA, 1999.

70. Salvini, G.; van Paassen, A.; Ligtenberg, A.; Carrero, G.C.; Bregt, A.K. A role-playing game as a tool to facilitate social learning and collective action towards Climate Smart Agriculture: Lessons learned from Apuí, Brazil. Environ. Sci. Policy 2016, 63, 113-121. [CrossRef]

71. Arias, E.G. Bottom-up neighbourhood revitalisation: A language approach for participatory decision support. Urban Stud. 1996, 33, 1831-1848. [CrossRef]

72. Ryan, T. The role of simulation gaming in policy-making. Syst. Res. Behav. Sci. Off. J. Int. Fed. Syst. Res. 2000, 17, 359-364. [CrossRef]

73. Franqueira, T. Creative Places for Collaborative Cities: Strategies to Enable the Convergence of Groups of People and Organizations for a Sustainable Urban Reactivation. Unpublished. Ph.D. Thesis, Politecnico Di Milano, Milan, Italy, 2009.

74. Figueira, J.; Greco, S.; Ehrgott, M. Multiple Criteria Decision Analysis: State of the Art Surveys; Springer Science \& Business Media: Berlin, Germany, 2005; Volume 78.

75. Ishizaka, A.; Nemery, P. Multi-Criteria Decision Analysis: Methods and Software; John Wiley \& Sons: Hoboken, NJ, USA, 2013.

76. Voß, J.P.; Kemp, R. Sustainability and Reflexive Governance: Introduction. In Reflexive Governance for Sustainable Development; Voß, J.P., Bauknecht, D., Kemp, R., Eds.; Edward Elgar Publishing: Cheltenham, UK, 2006; pp. 3-28. [CrossRef]

77. Michel, D. Foxes, Hedgehogs, and Greenhouse Governance: Knowledge, Uncertainty, and International Policy-making in a Warming World. Appl. Energy 2009, 86, 258-264. [CrossRef]

78. European Commission. Communication from the Commission to the European Parliament, the Council, the European Economic and Social Committee and the Committee of the Regions Closing the Loop-An Eu Action Plan For The Circular Economy; COM(2015) 614 Final; European Commission: Brussels, Belgium, 2015.

79. Murray, A.; Skene, K.; Haynes, K. The Circular Economy: An interdisciplinary exploration of the concept and application in a global context. J. Bus. Ethics 2017, 140, 369-380. [CrossRef]

80. Ayres, R.U.; Ayres, L.W. A Handbook of Industrial Ecology; Edward Elgar Publishing: Cheltenham, UK, 2002.

81. United Nations. Transforming Our World: The 2030 Agenda for Sustainable Development; A/RES/70/1; United Nations: New York, NY, USA, 2015; Available online: https://www.un.org/ga/search/view_doc.asp?symbol= $\mathrm{A} / \mathrm{RES} / 70 / 1 \&$ Lang $=\mathrm{E}$ (accessed on 30 November 2019).

82. Haas, W.; Krausmann, F.; Wiedenhofer, D.; Heinz, M. How Circular is the Global Economy? An Assessment of Material Flows, Waste Production, and Recycling in the European Union and the World in 2005. J. Ind. Ecol. 2015, 19, 765-777. [CrossRef]

83. Lahti, T.; Joakim Wincent, J.; Parida, V. A Definition and Theoretical Review of the Circular Economy, Value Creation, and Sustainable Business Models: Where AreWe Now and Where Should Research Move in the Future? Sustainability 2018, 10, 2799. [CrossRef]

84. Mat, N.; Cerceau, J. Economie Circulaire Et Stratégies Portuaires, Note Stratégique Et Prospective; Fondation Sefacil: Lamaneurs, France, 2015.

85. Merk, O.; Dang, T. The Effectiveness of Port-City Policies: A Comparative Approach; OECD Regional Development Working Papers; OECD Publishing: Paris, France, 2013; Volume 25, pp. 1-36. Available online: http://search.oecd.org/cfe/regional-policy/WP\%20Effectiveness\%20port-city\%20policies.pdf (accessed on 10 December 2019).

86. Gravagnuolo, A.; Angrisano, M.; Fusco Girard, L. Circular Economy Strategies in Eight Historic Port Cities: Criteria and Indicators Towards a Circular City Assessment Framework. Sustainability 2019, 11, 3512. [CrossRef]

87. Di Palma, M. L'economia Circolare: Una sfida culturale per le città portuali creative. BDC 2017, 17, 99-124.

88. Arvai, J.L.; Froschauer, A. Good Decisions, Bad Decisions: The Interaction of Process and Outcome in Evaluations of Decision Quality. J. Risk Res. 2010, 13, 845-859. [CrossRef] 
89. Loorbach, D.; Wittmayer, J.M.; Shiroyama, H.; Fujino, J.; Mizuguchi, S. (Eds.) Governance of Urban Sustainability Transitions: European and Asian Experiences; Springer: Berlin/Heidelberg, Germany, 2016.

90. Avelino, F.; Wittmayer, J. Shifting Power Relations in Sustainability Transitions: A Multi-actor Perspective. J. Environ. Policy Plan. 2016, 18, 628-649. [CrossRef]

(C) 2020 by the authors. Licensee MDPI, Basel, Switzerland. This article is an open access article distributed under the terms and conditions of the Creative Commons Attribution (CC BY) license (http://creativecommons.org/licenses/by/4.0/). 